のスきのに

章上で応つ人

にであ用い類

於あるのては

てるか真のよ

はか、の知り

省或課識占

左選は題をく色常生

様す势学活

䖭る可充求子

祭と可よ能

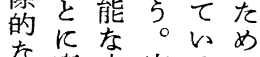

政搷方奉るに歖

策接法際。古探

樹的の $k$ 中㥲究

立関で会に视

参係、学々つ

与参或のか的

与る志衹て

るの意用答の

るで味昜あで智

合るど何かと

社公がが共

社従方な、资

学てがる会善

者とぶべ学悪

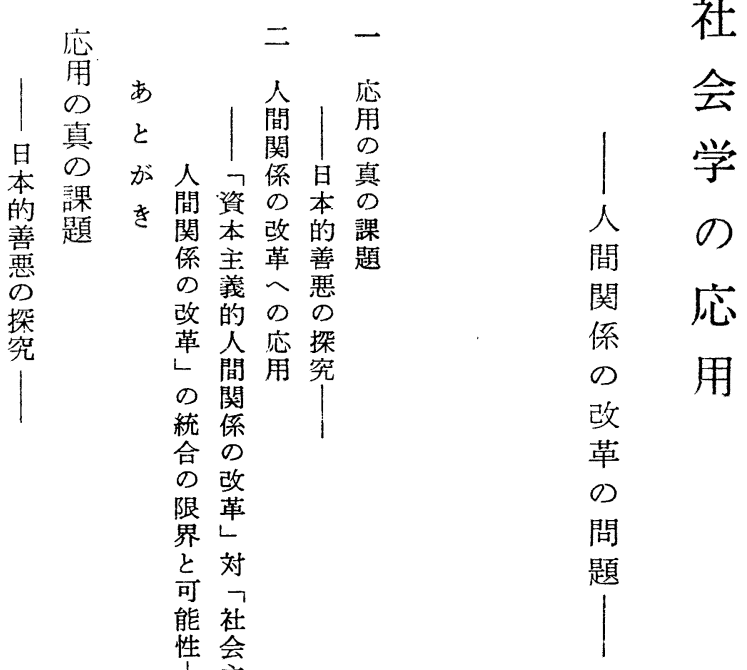

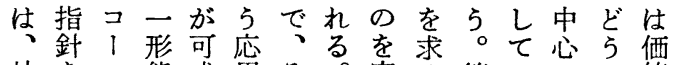
社を不態成用そ。実め第にとい值 会与をとりのれ第際よ一る検 5 判 の充単の增形ぞ牙家 5 のだ討方断 変る一比大態れ $\vec{\sigma}$ と形乃し法か 動との較しでの形提す態 5 よ にら 々パにてあ領態基るは加5 於超

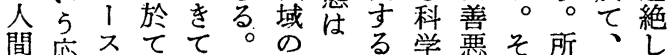
運の角 命形 $\bar{L}$ と学的 5 証 や態 1 上思の仕価間主ての学 5 観 福丠ブらわ現事值接義の形者程的 祉即飞。独況判的者価態省度中

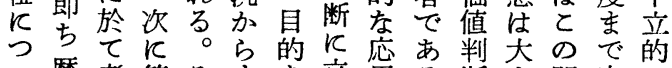

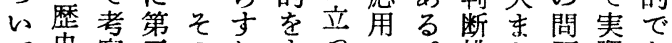
て史察言のれ\&つの排か題際あ

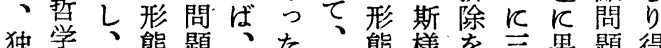
独学、態題、た態様を三果題得 断的人は点寒任研吕飞強つしにる 的形類人を際事究非科調飞て参か な態の類以的に盟常学し分ど与L 見で将社下 $K$ 参実 $儿$ 的、類の出又

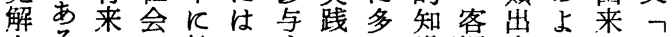
をるにの於とすと識観来 5 る 善つ全てのるいとそ性るにかの 良そい体、形と 5 忽ののだ対し場 なれて的第態型わ型わろ㠰を合 


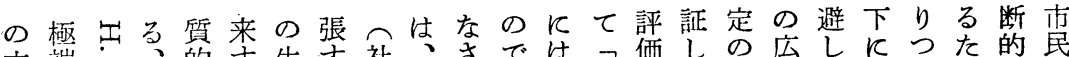
立端○的专生专社、さではフ価しの広しKつた的民 場な学々なる活る会われあ寄人さて社範於つめ洞に を型のい目自に構れるる罂間る来会な中てあの察説

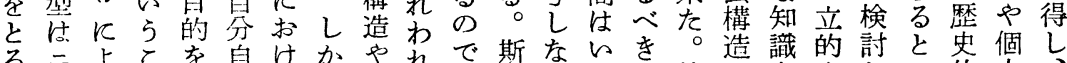
るこよてを自けかやれで斯ないを造識的討と史個し 社七れと達身るし文年あ様いかで絶とを立しい的人

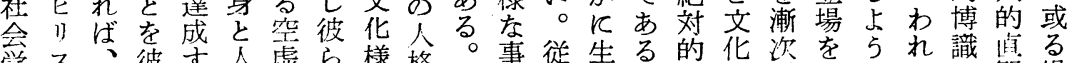

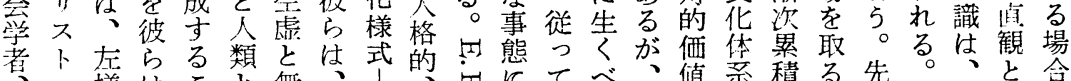

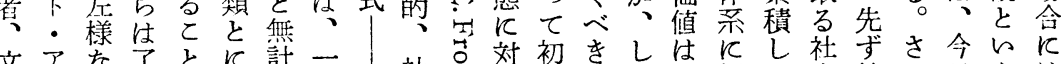

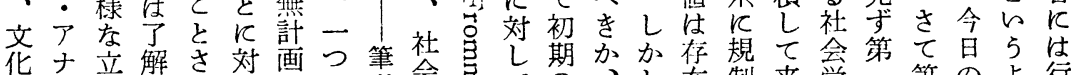

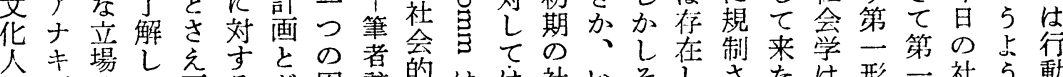
類で恃て不るが困註的は将社いそしさたは形一社 5 動 学么、心可信、難奨次、会かれなれ。態形会なへ 者で正な能頼即なに莱学学にはらるそ人態学—と はあにいにのち事よが如新に行単と相し間上と者つ歌

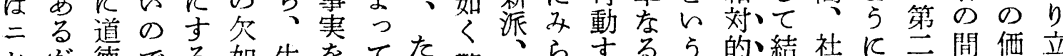

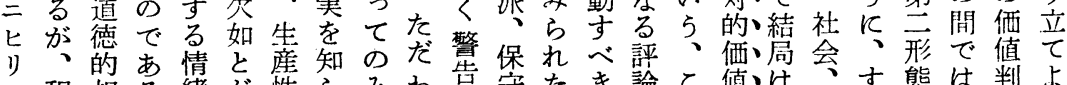
下程相る緒が性ら少告守たき論と值は令す態は判上 卜度対し。的、の保扎発派建かやので、文べの二断5

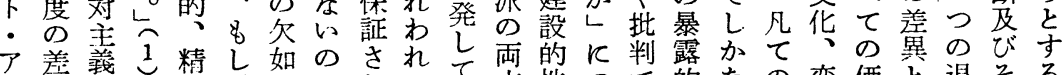
ナとでま神長とでれのて方性つで的なの变価と退そる キ之ああた的引、あて物了出格いあ役い価動值問化机。 ズありて妨けそるい質る。るをて割て值に判題器を左

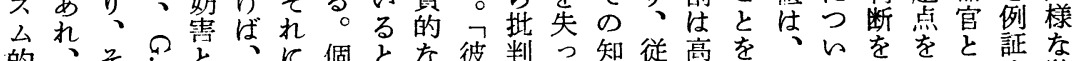
的てそ它と物由個とな彼判っ知従高を例特て回以をと証な

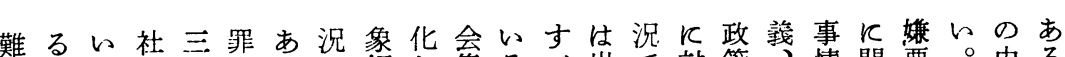
でとと会者事るに領し集るへ出で詨策客情関悪。中る

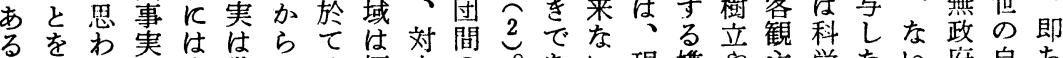

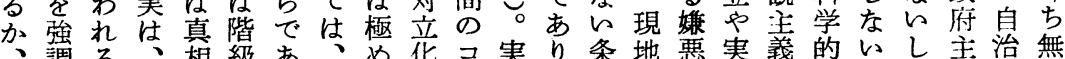

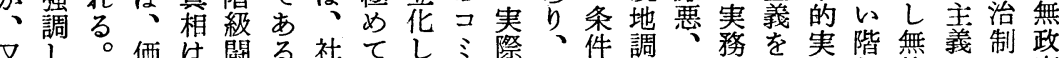
又

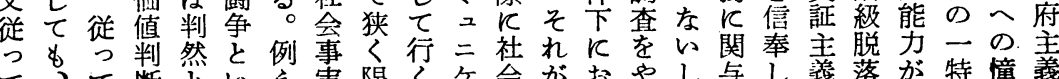
て、て断然的费限くケ会が扔やし与し義落が特憧義 第実単のし5壮定現 1 の七かる無专、者分举徵れの 一際に基な強最のさ代シ近ュれ赛能る一に子げとに分 形問価碟々ら近\&れ社 $ヨ$ 代 I て証力と切\&のらし過散

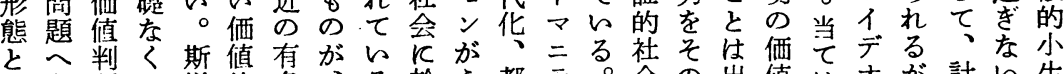
思参断し様的名、る於 5 都テ。会の出值はオが計い生 わ与排て飞、強とてす市々従学特来判志品々画し産

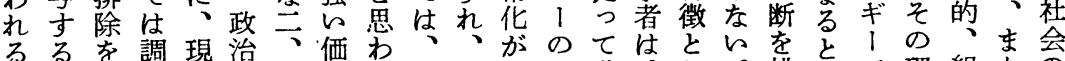

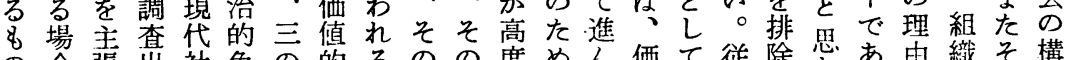
の合張出社色の的るのの度めん価て徒除惫あ由織々構

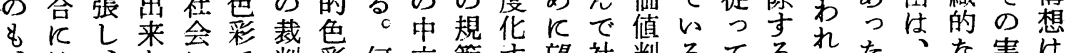

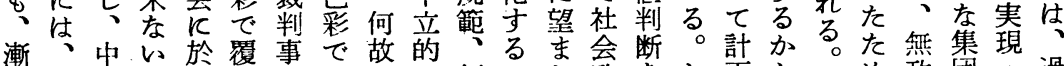
次々立事てわ件覆な立価飞し政をし画ら彼め政団の過 第れ前事はれをわら場值つい策回か的、彼で府行可去

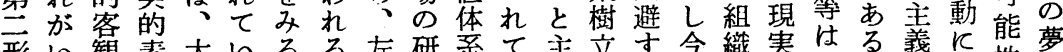

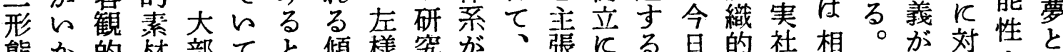
態か的㭝部てと傾様究が、張飞る日的社相。が対性と

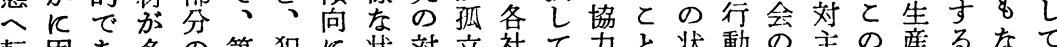
転困あ多の第犯に状対立社て力と状動の主の産るなて 
ズ其ないでど実とらそ等と題し用に来用はつ婜関ジ身 厶他主人あのへでとれしいと得し於るし、い吉係二せ とに体関るよのあとをく 5 する得てと得同て总管㕕ざ 於的の。5関るは主主主るしるととる—み琵報る

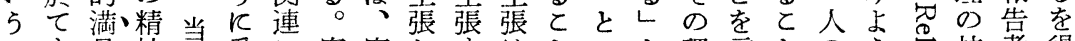
普8足神初受に客客し守はとにと理言との 5 竞技者得 遍使を的飞け於観観てる、年 的用第物於とて的的い所産く主 5 をし主術シ寻焉あい 倫さ一質てら奉科科るで業、張と述た張者ンし襾っと

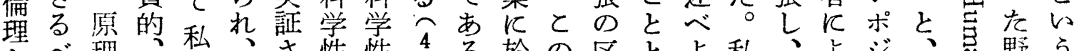

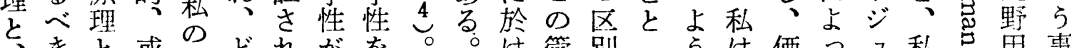

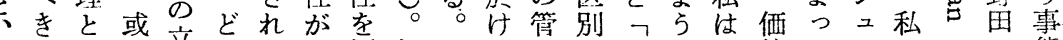

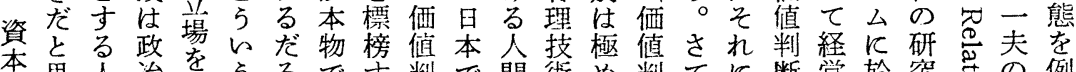
本思人治を5ろで卞判で間術め判てに断営於究芯の例

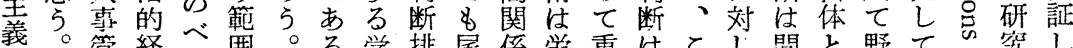
乃、管経れ囲。る学排尾係学重はとし間と野て心究し

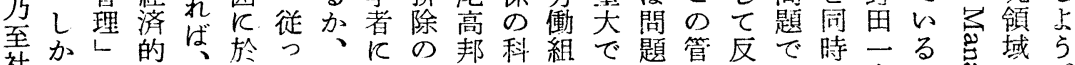
社しのなで仮と立堆学合あで理対な反夫怘で。

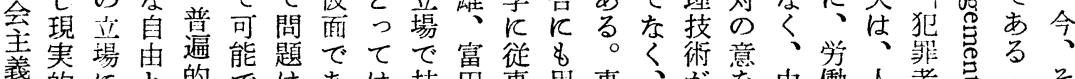

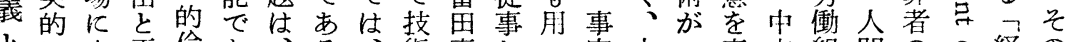

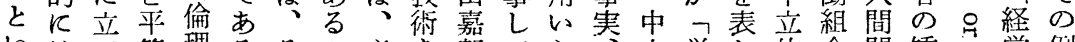
い年等理るそか必を郎てら立学し的合関矯与営例 ら、ばとのかれは要使等いる価的衝た立に係正気と 社ヒ、い立とが、不用多るべ值立組合場\&管の字於し

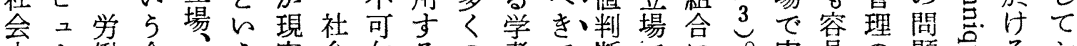
内1働全、5奏会欠るの者で断でに。赛易の題葍るシ 存?組面、即と的的のと人があり実\&以施飞技し思人ン 的二合的ちとに現といが、る、問施適下出適術にる゙間 ポ

の労よのと等技の問を状関於にが論科普実応もると倫 内働 5 はなを自題置態係て、、争学、遍的用適のし理

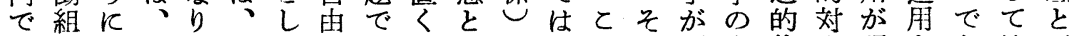
は合思現、政てとあといとっとれ既名倫立現さあはが

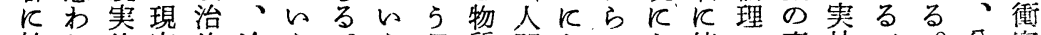

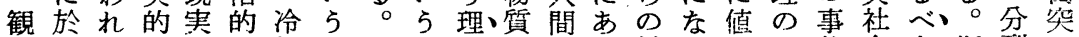
念てるな的改視政日、想的のる热さ竞態会き、斯烈 ᄂ の、。物な革し治本単的な主の判れな場て合で様し、

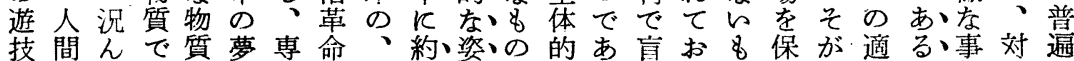
と関やあ生をらを今束、へ満る点りの持問用し態立的 乙係、り活す消夢、日的於経足。と、で出題でととし、性

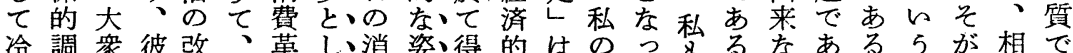

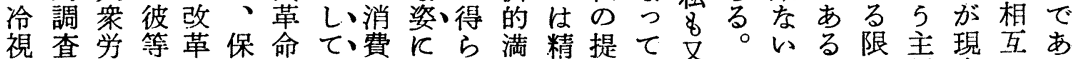

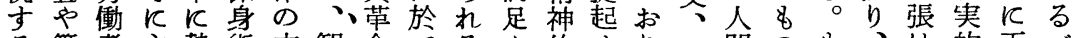

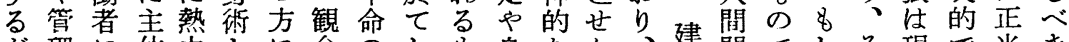
だ理に体中とに念のし\&良なん、建関でしそ現で当き

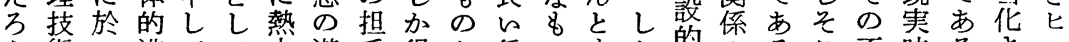
5 術て満てて虫遊手得か賃の方加的のると不味るさ之 。を足いはし技でら金つる8立科とに可をかれ 強使やをる、てとあれ又政問本場学吉於避持らる、 力用で与。むいしるな精と治題質でにれて的ち、所二 なしあ方彼しるて虫々神の的は的 $\Leftrightarrow$ 代、な得単にズ

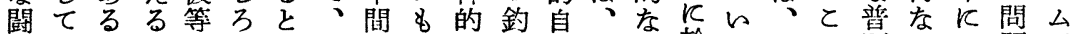
争\&。のが政ら学階のな合由日問於てその遍ら題が 態、今は信治わ生層か子多や本題てはれ管的の労の現 势彼か金用的れ運は、のの良の点検、は理倫で㗢本実 を等りです保る動、とにとい現は討各客技理あ組質的 必汁ある守。的人的重れ人況括観術のる合が形 要心方多派彼間 5 点た間飞正るの的が現。にあ態 
コ的クモで於近人技の的害をの閥最含於重在同るは的時。定組を 卜揭シラるは経関は卡的め後けで事的当経依る幹る の ザ1 シが、営係適層つ研与のるあ情奏初済然社部労

低るの 1 、能学技用部の究 5 問人るが現飞的と会の組 下立理の後率と術出の問と。題間。あと述渾し的独を を場念理者のの論来価題同さは関フりそべ足て状占除 第女の念に上間のな値をして

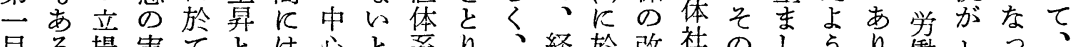

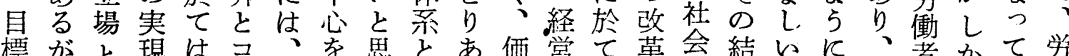

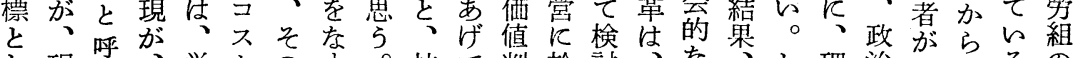
ᄂ現ぶ、学卜の方。技て判於討、な理治主しるの

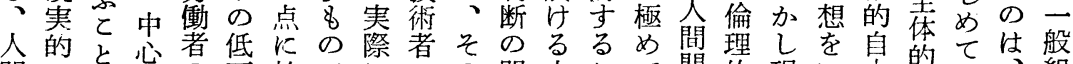

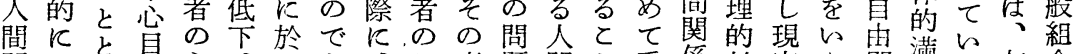

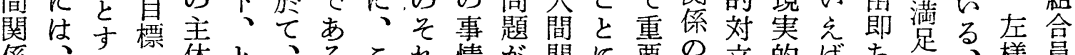
係、るで体と、るとれ情が関に要の立的ばち足る様員 の前可的い明。のと重係しな改やに良をとなの 改者しあ満 5 ら即問が検要管た間革激は経いかと潜精 革飞勿。足営かち題一討で理。題し笑、済人ちい在神 は於論っを利な、性しあのととのを之致し間 5 え的的 て㠃第目差伝、しる技と考一引ら満関るよ価活 第は二上的賈統経な5 と術でえ環きな足係た 一、つを原がが的営く。思にはると起りとはぬ。観が 目能のの理、あ経組て第わ於、。し寸得政第の今と低 標率目章と中る営織は一れて当従て事な治第日調 達の標場专心。学飞、反る8面っ、奏い的次一のそで 成上ををる的前と於管経。て経と社自的の状れあ の昇三デ、目者、け理虽具他問、唃去会由で前況をり 条、元モデ標に最るの体体の題そ体が呙のあ提で規

る場シ自は人な方とで時化想係る決 $\widehat{5}$ の概くではは件

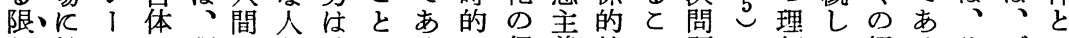
り、於のが理関間、とろに促義技と題従想て経るそデい 飞、て理、想係関あは5 お進的術がで從主、営。のモ5 於は念経主で係や、してと人は先あて義能組し目ク資 て、重に営義あはまと覔な七間不決るて的率織か標ラ格

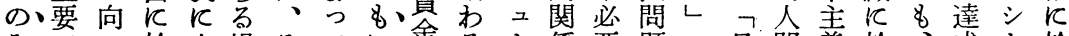

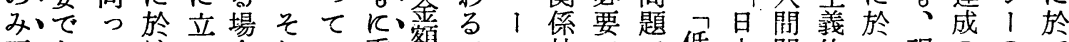
正あてけて合れい重額べ技でで焦本関的い現ののて しる改るばす自る要ををン術ああ賃の係人て実条理の

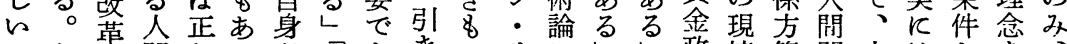

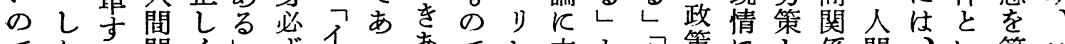

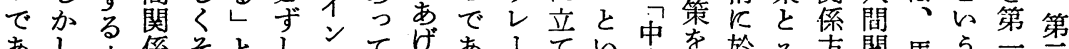

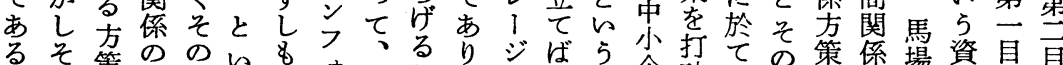

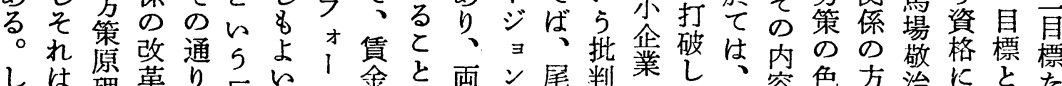
か経理をで区革りマ鍂と者ズ高がが、組容急策治にと於とた

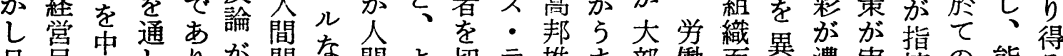
日自心しりが関な間占切テ雄充部動面異濃塞摘の能る

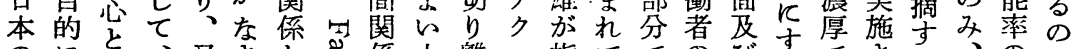

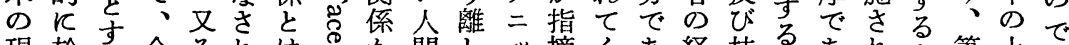

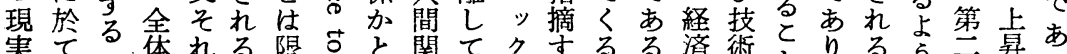

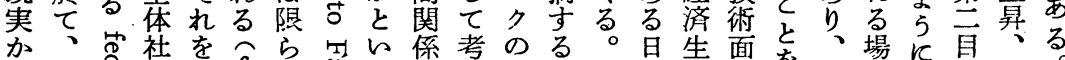

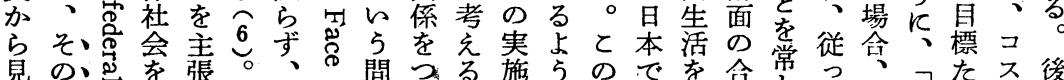
見の导張。、の問つる施らのでを全党つ、フたス後 れ立悹デす之上の題くのとに場は安理导てそ現り卜者 ば場るモるのく人のりはは、合人定华るすれ代得のに をのクと反な格た出䛊、合間さがる上㤝のる低於 経取立ラと論け的てすり同理理関せ先レ記、多の下て 
をっ間業るらるあ主運にでが最的場要に績のとす経営 改て関家芸と。る義営三、、近裏合件政を結さる済者 革い係に術す従。とに十マドの付はを治示身孔民洒側 しる管妥家れつ要の於数ルイドが、保のしとて主值に て企理協的ばて守闑け年クッイ必左証方てしい主を於 業の世経、日る争る以及社少要様す式いてる義中て 真家技ざ営経本飞を失前主民社となるとる、傾は心は のを術る者営の、経敗で義党民さ段\&しの労向、と能 デ探をををを現現て、あのが党れ階のてで使が経す率

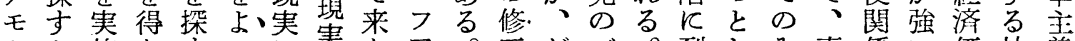

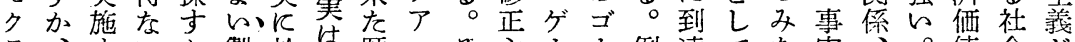

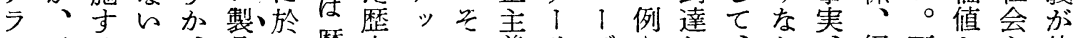
シ又るの、品てて歴史シの義りデえし、ら 経晒と主依

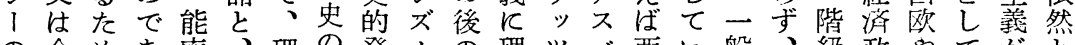
の企めあ率、理の発么の理ツべ西的般、級政やてがと 理業のる主占想裏展へ歷論網儿欧る的経主策アの第し 念家第。義い主付のの史的領ク的と認済義、メ社一て の正従の小義け結完的にや綱デは識的が社り会目強 信経步っ仮間的飞禁全過優八領モいを安薄会力主標い 奉営在て面を人よで敗程位イ゙がク兄得定弱保に義でし 者者、、を作閆つあ北志デ論うなて、化障於とあ

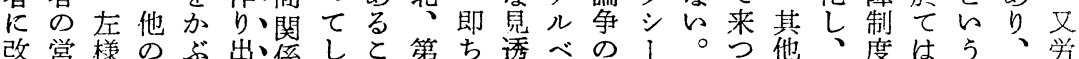

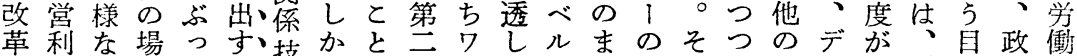
寸目価合たと、技生を次イを七と好れあ人モ極長的治者 る的值と理と術れ認大マ得網に範飞る間々めとの価侧 とと的同想とを識戦】た領な例はがのうて歴た值に とい立じ主考事いす後ルのとつと長、基シ進史めを於

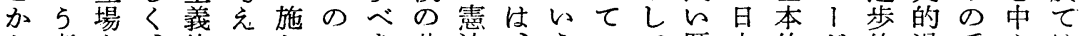
ら考を、的てしでき共法、5 5 て歴本的が的過手心は 出えと人企々よあで産の既姿る、史の諸単成程段と

実主対のへも的そとすと的己入のえ約はシい営がな発 の義立目の志役ののと発と保る欲て内、1る組明いせ

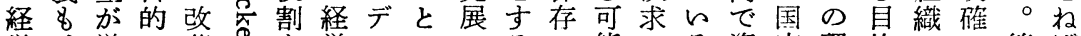
営、厳に革丹営モででるの能でる資家理的ので第ば 組営存はのの演組クああ後欲性あ最本や念飞目交云

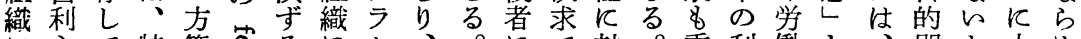

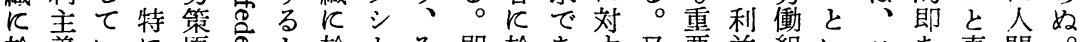

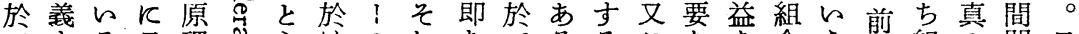
てもる日理气主けのれちてるるて㕝 5 述組の関日

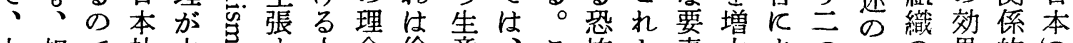
人相で社中马捻倫産、と怖と素大よつ如の果的の 間対あ会心とる間に理物それへ表はさりのく最は技現 関的るのといの関向的をのにバ裏、せ或立簡上望淮情 係存。特な5で係つな製理対 1 の企る種場単部めをで の在社殊る用あのて高造想しナ䦐業このがにとな適は、

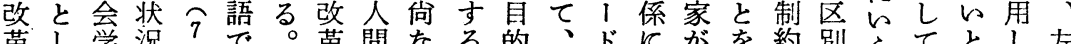

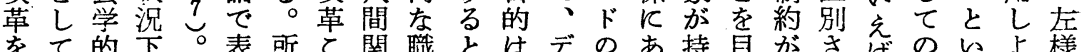

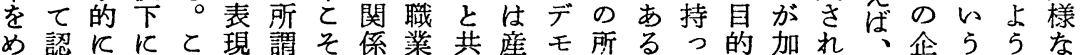
ざ識見於のさ势のでに業ク謂所てとえるて業とと経

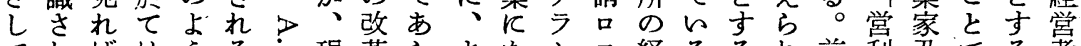
てればはらる。現革らよたシス経るるれ前利乃でる者

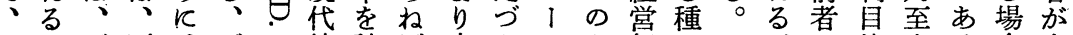
そわデ両、デ占社計ば良さの恐組令とが的企る合多

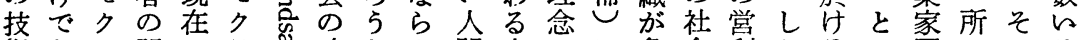
術あラ間のラ总改と如間人のに危会利かるつ団でのる

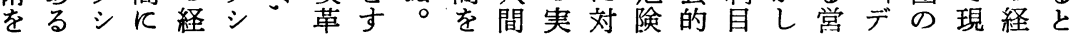

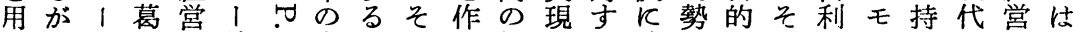
ら、理藤組社中。しり福をる落力をの目.クっの目思 上現想と織会. 核又七出祉自自古へ支制的ラて経的气 
イる党だ表ち議に於びのているのれ於のにい立モも市 5 モ。少守現飞はけ低状経政理てて実於証的ク石 ン今総いる在於、る賃態済治念いは現て抛なラそ。市

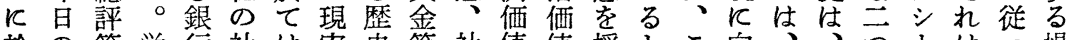
於の等労行社 は実史等社值值採とと向、、う１はつ場 け経と衝等会、は的と会とで択考のつ経現のの相て合 る営ら者|体経好、ん保しししえ自て営実倫理対、に オ組 5 側制営理社 5 障てかたる覚絶組の理念的例は

1織外ににを者出会経制のなとのにえ織労にが洒え ソ理面於強維層来的済度社いしは基ざの働転、值ばい リ論的てく持はな、政の会学てナづる最芓化現でデず

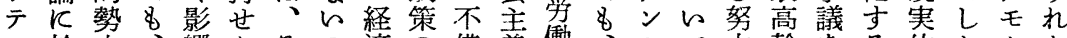
亿於力、響んその済の備義働、七て力幹をる的かクか 1 て現さとれで的欠落学ンデが部自かになラの の、影在れすとあな陮潜あの衝スモ要とれらはいシ価

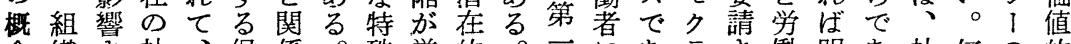
念織さ社、保係。殊旋的。二にあラさ㗢明あ社何の的 はにれ会上守を例状存過そ貝とるシれ組白る会故理選 そ於て体記政母況し剩と標っ。1る合で。内念択 のけ、制の党っ将とて人に恃て例の。のあそ在らとを

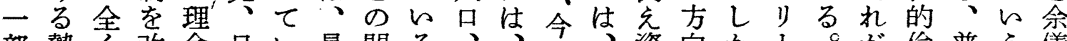
部勢く改念日 と力同革を経る近連。国学のデ本へしダデ完理遍目な 思へじせ塞連外のを斯際使とモ家の今1モ全飞的的く わ車ん現面大样市関とク協日達クで規倫をさ れ、態とす金的規っな場係ろラデ力のはラ、制理とせ

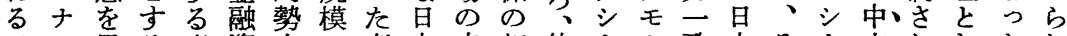
が!呈る意㕠力の考本末相依门ク致本そ!立れしたれ レ゙し革欲本|労察社拡互然はラが社のの的ててとる の、て新はを|衝な会張不と単シな会理理で、のしの 分サい政甚代即争し质信しは、さ念念な対デてで

飞こ延さ!值嫢る決值客あ批るな盗い的日の労営現析

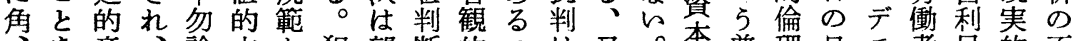
を意、論立加犯望断的合は又。本普理日モ者目的不

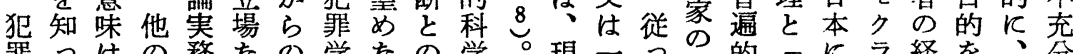

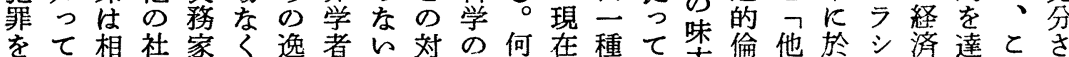
減的会でし脱はで決名故の星方理人て1的成のが

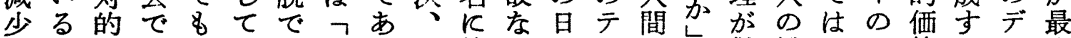
さ。なは|は犯ら日值ら本不関併餓立值るモ大

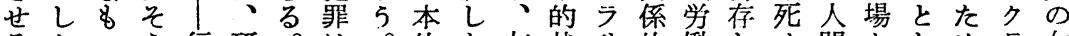
るかの 5 行研。は。的な左状り的働しせ問かしめラ不 としでで為究不悪と善い杽況ズ技者てルは、てのシ樎 共ど、なのに適らの悪もな反ム術のらと自との手、と

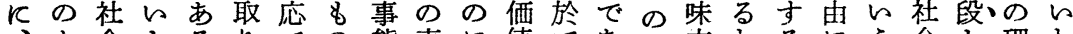
与会とるりでの態真飞值てあ谪方わるに5会と理わ 犯 5 反型組あでは鈖判とる週かけ状快対主し念れ

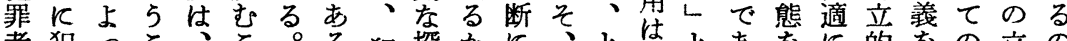

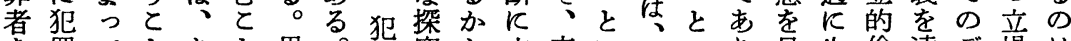

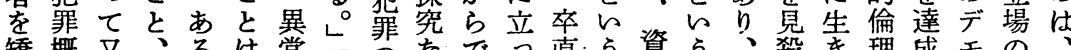
矯概又、るは常沓なでっ直 5 資 5 、殺を理成モの

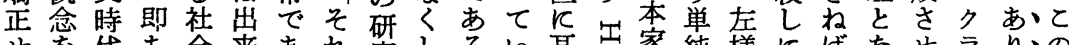

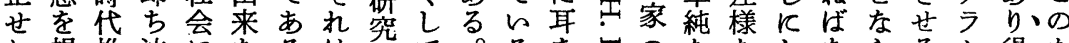
ね規推法になるはにて。るを占のななしならる得た

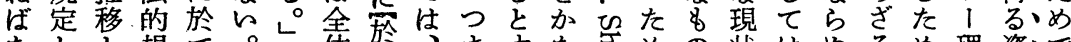

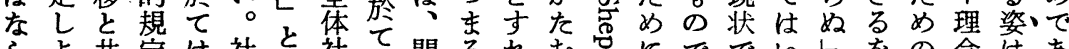

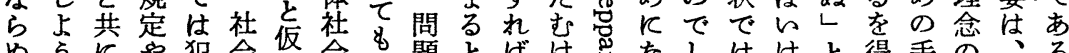

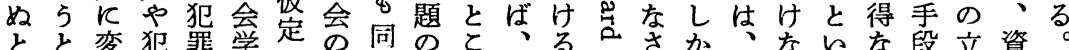

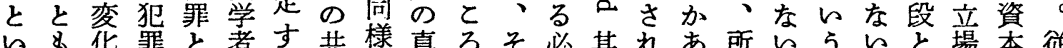

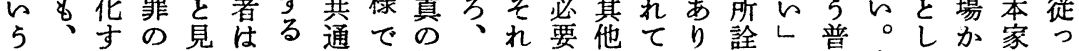
積鬼る外做|価のあ解価はがのい得はと遍今て、等 
て犯に果 5 び刑後理論はにに立実一ら対はが一の政極 罪よかな社䚯の念的法適よと証方な立行一飞途策的

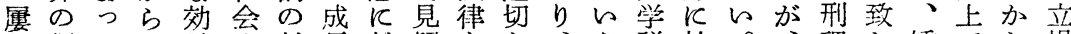
々類てし果生対長対解をな、5 説於。、理し矯でら場 型はて的活象と比飞恐刊社姿的て周現論な正の萔な 犯 罪何決犯遇適り展せ礎、を秩於場罰のの於限区具孤し 法等し.罪飞応除飞らをそ科序て、刑通行けりの体立て ののて者集さ外目れ置の古を要精的り刑る、当的しは 全相改の中せす標るいたる破約神立、政刑奏路なて研 体互造性さるるが理てめこ壞さ病場行治罰験者問は究 的依さ格るととお想いにとせれ理古刑飞主的や題考出 目存れはべと共か主る設をんる学克理於義研又点え来 的、を年をる義。定眼と。的典論てと究現をらを

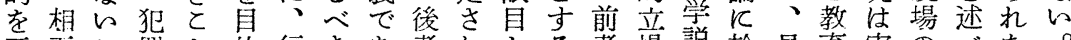
否互と翡と的行をあ者れとる者場説於具育実の心゙な。 定関と類をと刑だるは喜意をと的け体主施施ていそ 寸係、型主すのと。、法る志、新的義出設、。の

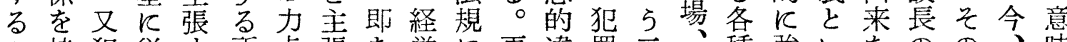
の持犯従于所点張ち党飞更違罪三々種強いなのの、味

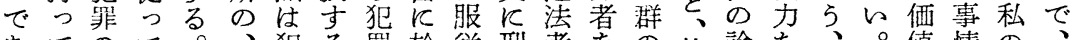
あてのて。、犯る罪於従刑者をの他論な、。值情の、 る心動彼更各罪。者け专罚之法価方争力三何的を経研 。機等に個者従のるるが見律值、はをつ故立明験究 斯いはを実人をつ矯デだ重做に的教、持ので場白か者 様と、処証に回て正モろいし違、簡つ価あとにらの 飞とそ遇的適復精はク5な反学刑単か值る私し矯主 三をの守研合さ神、ラとらそ理的飞ら的かの占題

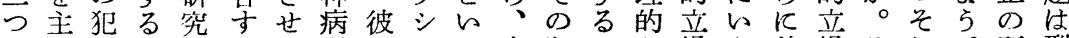
の張しとのる者の门5人犯と場え外場それ。研刑 対したと結よ再を今の理々罪と詨、岁なのれと第究事

でるれは代権は建つ見值つそ業体のと值と即儿当は照 あ各ら現性利、設資た目てと社的かちど然、的 る種一奏、の前に本場標規飞階可会真側ら理不で法見 。の捙の全み者挺主合の制は級変の面出想可あ律解 し価の日体主の身義の設さ普等的最矯飞発主能る学は 加值三本性張場专社矯定れ遍ので大正於し義飞。出決 し中永社

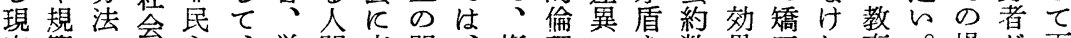
実範の会、労間辛問、複理飞学数果正れ亩。場が両 問を複適制解働に捧題斯雑がよ含とはしば主か合多立 題、雑合等雇搾す出をの存っんし望占な義く的し

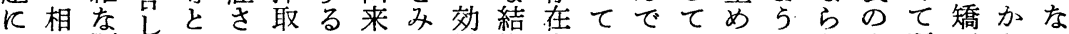
取対順ないれにとるよ果構す、いのなとな立研正らい

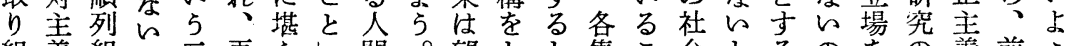
組義組の云再えし間。望とと集と会とるのをの義前ら 吉の合が炃犯らでにそめつ共団と的ら際で取第の者に

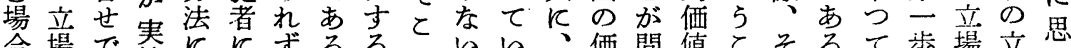

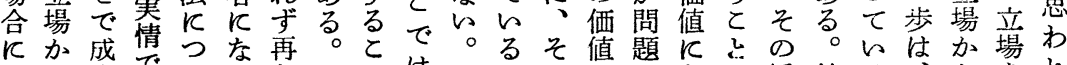

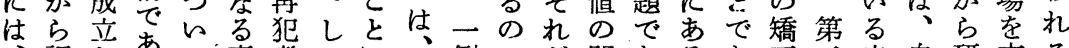

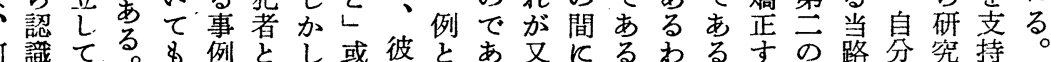

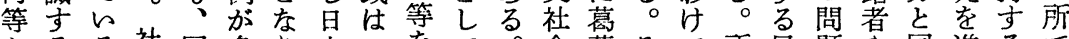
かるる社同多り本皇て会藤そで所目題や同進るで のと現会じら、の社改、従丙とれあで標は施しめ人施 価と赛学ら。後現会造社っ在詨はる目が、設価る達設 值が社的三封者況主方会て的立、が標明犯長值てが長 判中会K者建の況義る陌単倫が年、は確罪を的と多や 断心仝択性場飞社目級一理あ令そ心著探立は心当 の問於、而合於会標的のにる、れ現な考場、の路 選題けとで近尔て应価よ。職自在い価と殆は者 


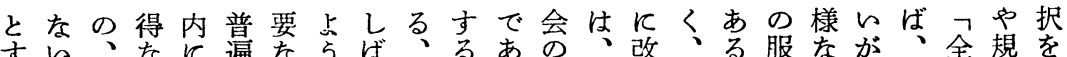
る事資心生的規飞殺とそる倫と造現。従立、喰体範余 対情本の存適範見人主れ、理の宩在し者場実わ社に儀 抗主でし用がせに張らと的事るのかにに務ん会嫢な 的即義あて性、か対しの主規情K資し矯立家がの制く なち的るいと人けすょ規張範を過本斯正つはを価ささ 普死倫。るを間らるら範すが次ぎ主様して逸め值れせ 遍飞理し限与存れ禁とがる、のな義なよ、脱のしたら 的直がかりえ在る歨す、でそ如社立 5 逸行壳か個れ 倫面、し、ら反淂と脱動春ら人る 理し普日左れ本か同の間乃成説的体は者と逸がの がた遍本樣る来くじで存 5 員明 5 制、るを考、脱、で 存初的のなの的の5あ在しのし批加普方しえ逸し現あ 立困倫現倫でな如 5 るの、すて判ら遍法てな脱た在る

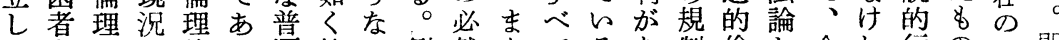
得を飞飞的る遍特例然たてるな制倫と全れ行の社即 る社類於規。。的殊人え性現に。ささ理政体ば動と会 、

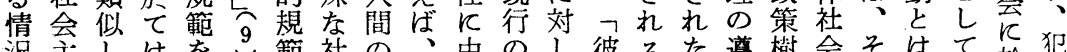

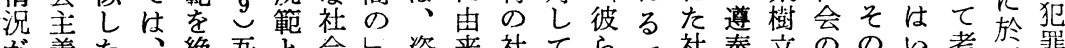
が義た、絶吾と会し盗来社てらで社奉立ののい考然罪

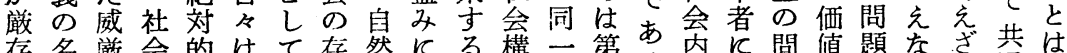

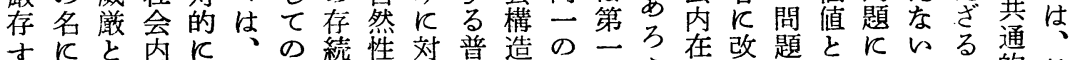

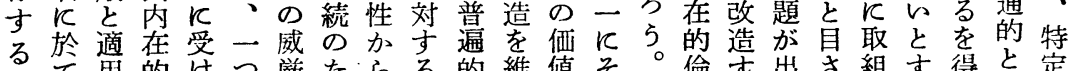
るて角的けつ㛜たらる的維值々。倫势出さ組专得々定 の救性倫入のとめく禁な持をの鲗理る発れめるな洘集

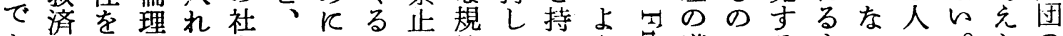

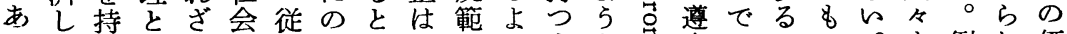
るよ占しる体つみ心しで

所の対にれとと藤て革会とる体育 5 型場に於し. 依餓つ 謂底守於れれしし、で改を。飞、。態合於てて然死人 技意るて学ら化て依茧認今於家前のにて私吾とさ間

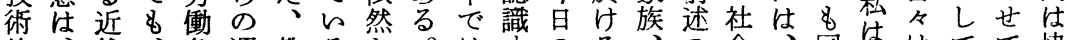

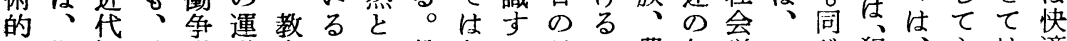
な単性社議動吉。し教なべ日フ農如学一じ犯、主は適

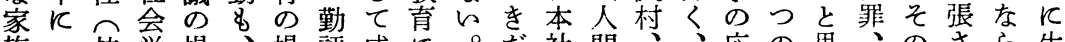
族二核学場、場評成飞。だ社間、応の思、のさら生 緊つ心省合教飞斗功於政。会関都こ用価わ産一れぬ.き 張の家要と充於争主て治従は係市のは值れ業方ねしね の、族、同とけは義は価つ、の型、判るのだばとば 調静し無じ関るそそ㸓本断が領けない必改学 整態と意く連フの能デと、ず革働は質に域のららら

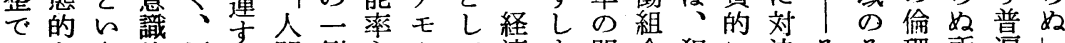

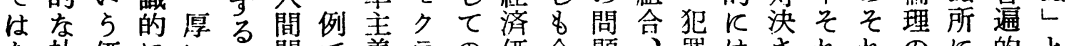
な社価にい备関で義うの価全題、罪はされれのに的と く会值前壁条係あ、シ、值面し官と、せがぞ選問倫い 、体的近筑種のる権、デと的は公産第ら何れ択題理 5 デ制な代ぶの改。威理モしな、庁業云れ等にれをのが普

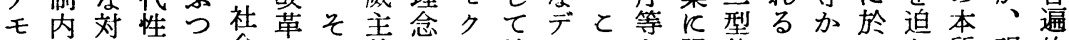
クの立系か会しれ義のラ社モとあ限態とのてら質現的

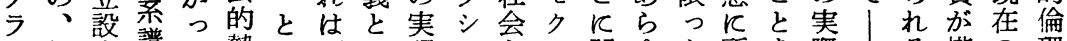
シ福定譜て勢しデい現门主ラ関ゆた所を際るる棈の理

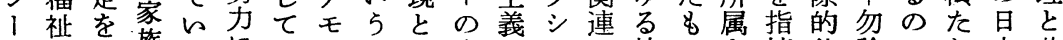
の学淕族るにとク目い完の!社のさ摘仕論でわ本共、 理的 み福。占ら的 5 , 成実社て会でせし.事そあっ社に、 念病て複家つえ方古自現会く集はらたにのるて会、 理い嗄族て の学る家の影机立飞社みなの族るる左与の以於人 家的。族研響る目亲対会がらで組。だ様守領上。て間 族なそに究さ。的葛し改社とあ織教乃なる域にそ、を 
情理のれをましつげ型用方めくで団改団織面発あに関 熱解信はスたてたて態の法てつあに革ににか見乃つ係 こす念極ポあ個偽、当の、人る一は於於ら出らいの そるやめンる人の実於面棕実間。貫|けけ取来。て改 がた洒てサ立的中任ての合り関そしるるりる同の革

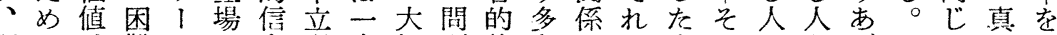
調の、難にで念者方切題体きのは全の間間げそょの意

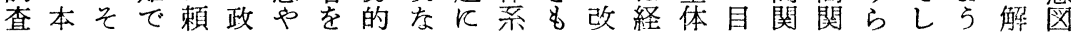
を睤とあっ筑価区なとつ的の革営社標係係れてな決し 企的かるてを值別価といなにの学会がののる、無はて 画なら。い提をす值はて繶な問やとデ改改とそ意、い し不引前る唱する判、論合る題教しモ革革とと識イる 、可を述場すてと断真をのでし育てク\&ががに的デと 誘欠出し合る、とを進問あと学のラ重重期於価才考 導のさたはと冷でや中め題ろんの、シ要要待て值口总 寸条れよ刎と静あっ立よに5 5 領目1 でとさも設ギら る件る 5 論はでるて的 5 あ。旗域的であ主れ、定1れ

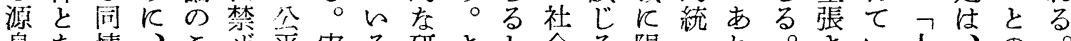
泉な情、とせ平実る研さと会る限一㧈。さん人、の。 とると現とらで証所究て思学し定性、寸れる間社対类 なか情代、れあ的の者価 5 ののさ の゙社べるの関会決際 るら熱社そるる調、と值。忍下る前会てとで係学なに のでと会の。と查科、判し用にべ提主と同あののく家 であ气に他しとに学実断かの統をな義れじる改多し族 あるが於のかが於と証排し中一母くでらく。革くての る。、て場し要ていの除と核さのしあの、かののは堅

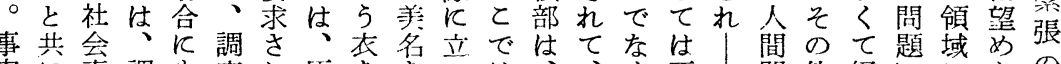

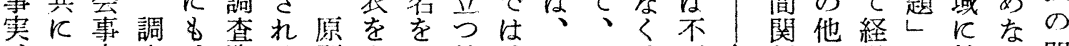
之実查、資る則ま加第、そは、可各係の営が於ら問 人のを者そ金。ととか一応のじ広能集の集組正てで題

そ会力り本るでて徐てに情死犯刑例用そたで在正と間

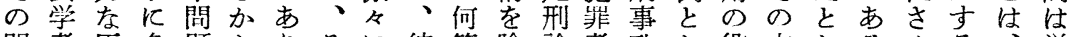
問者圧多題らりそに彼等除論者政し役衣しるせる、学 題の力くで、、の認ののく者個策て割をて。て帑バ者 を仕にのあと現感識主効たの人学、はぬ塞い力イも 強事よ望るの在情、さ張果め唯の者大存ぎ何際るでア含 めはつをட方のをせのをの一矯と要在す等生かあ 左てしと面社增る根\&唯の正社次守てな活らるをて

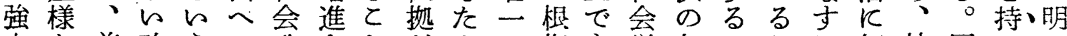
力な前改 5の政さとがぬの执も学如のとに何社同つら な改面革社応策せで感と方はな诸くでと值等会時なか 世革にが会用者るあ情ら法くくののあがし.関政にとに 論を押長政ががだると５梦、協べる望な係策社らバ を必し蛇策重当け。い事、罰又力て。娄的飞に会5 イ

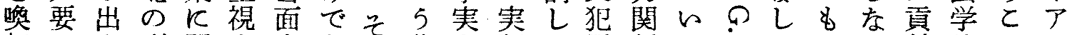
起とさ列関さすあの非を証よ罪係る江いのい献的と不 寸すれをしれるる他合知的 5 を杜势。でよ出調でを

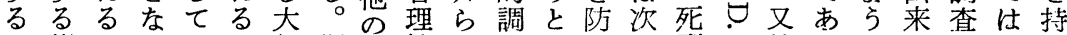
と諸のしのと部斯方性せ查い止の刑 2 純るなる

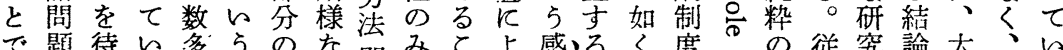

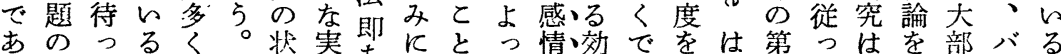

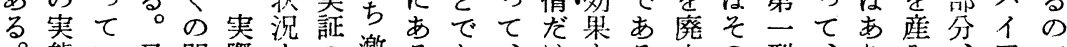

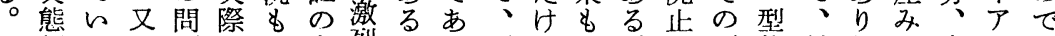
し調るそ題飞、も烈とる死でな。可態偽得出実 か查のれが こつなと。刑あり元せ能に市なす際をる しKではあとれ効論をそがる。来与性於中い努的認。 左上あ世るれと果争、れ犯。従吉与をて立し力目識大 様つる論。と似はは本飞翡そっ死と犯\&者、が的し切

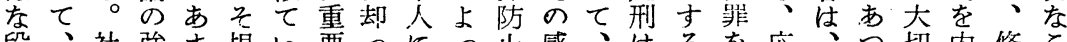

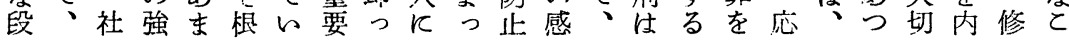


る第その用営と織殊現て、咇の第関り研於農第かい階 ○のはさ利しや状在はキギ要激三係組究け村一元かに 第組大労れ目七労況の㛉小とし型的儿、る都型っら於 合会働る的実働が日理と的態技で即人市態て、て 組員社者可の施組あ本出の、る変の術らち間の的今進8 合とは大能手し合る社来刘か動重、る二斛コ研日儿社 員が給臬性段よにと会な決らの複犯。つ係ミ究ので会 に対与でがと 5 於とにら交で過の罪農の的ュ、日社学 於立水あ極しとけを於段く河程事者村価研: 即本会者 て準るめて专る認て階しいが態の経值究号テちの政は

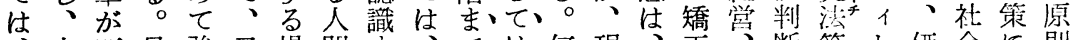
人可最強又場間于、では、何現、正、断等 1 価会飞則 営権成近く階合関る単来処故在何技都にはの值学協と 利侵りの、級で係とにて、理なのを術市立そ実判者力し

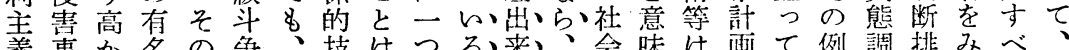
義事か名の承、技はつる来、会味は画て例調排みべ、 と件っな結と現術極のかな、現学すそへ、゙查除上を侕

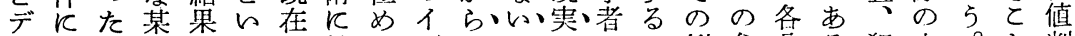
七ま製 5 の於てデでしいののか例参分る犯立。と判 クで\&紙思目状て重才あ、、社価。で与野。罪場そを断 ラ及拘会い的況、要口る只值そあ、反他のかの主加 シルわ社ものでデでギ。そ変的れる経於方統ら多張ら Iだらのかた㤌モあ、との動協は。営てに計研くし免

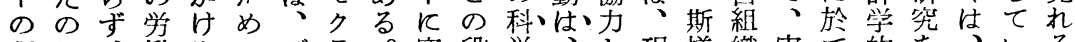
理は、働ぬのデラ。突段学、と現様織䒠て的を、いる

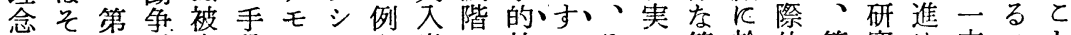

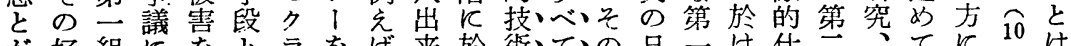

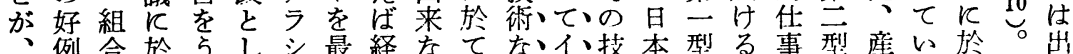

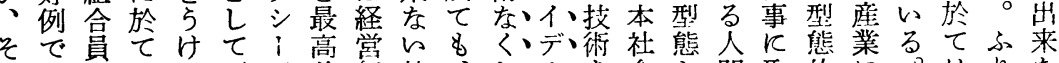
れあと、る悪が善組特、しオ旗と間取的に。はりな

与達て又経期值もりとし証た互団替のるるのちて目な

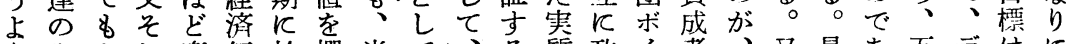
らみよれ楽価於撰米て、る質政イ者、又最あ互デはに にがら以呑值て択国高又価的治コの特そ近るにモ依二 純の外家とは出やめ個值価的ッ村徵の二。人弓然元 嘴粋でのにし来ソら人と值価公公で年斯閒ラと的 でにあ末なて第る連れのしに值等分あで間様性シしに

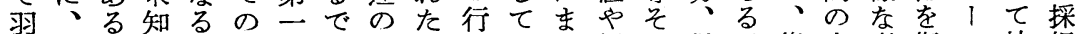
根科。の必デ型あ大時動、で経の勤。集人事傷の社択 を学し善要モ態乃部との生高済例評町団権態つ第会さ

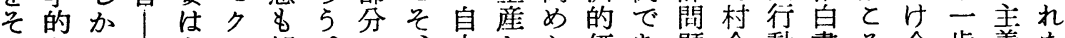

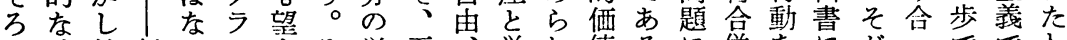

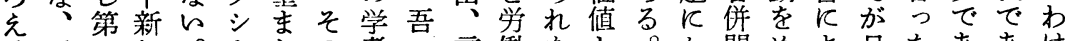
るアーし。「しの者々言衝たと。か問めち日たああけ よ力型い両やい意がは論と時い要ら題ぐれ本とるつで

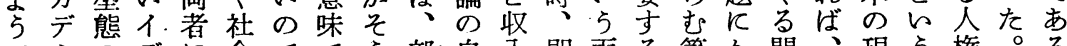
でミのデと会ででら部自入即両る第か問、現 5 権。る

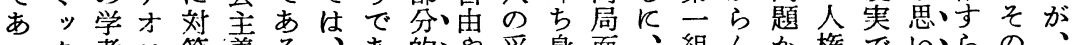
つク者口等義る、あ的や妥身面、組んか権でいらの、 てなはギのを。今る、結当体を民合でら侵あも、侵長第 は研、1 比絶事日上若社な的々主員、起犯るか害期一 な究だの重対雪のう午の関精な主に合る事とけさ間組 らを加可を善如飞の自係神え義占併侵件と妨合 ぬしら能与で単き躊問由を的たやる反犯がを害た泥員 。乙と性えあな旦躇題を保健、社第対が二知檼の試反 何的的てるる本なを保証康一会等激万智だの合於 故るっ比安と政社く残証すと買主組增件るけで的て

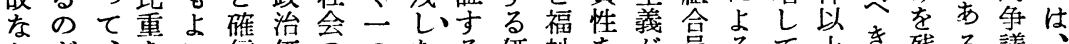

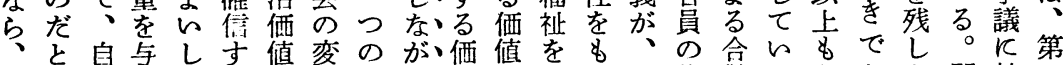

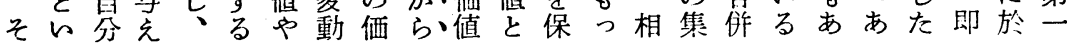


けを解る状本た生れ遍らデのるて故よいでの れ鋭決と況のだ活は的見乇改と、反りかあ研 ばくをとに歷、を、倫れク革と第、良らり究 二な探求は於史そ実社理ばラのは第いで、も ら求めなてにれ現会といシ問明型三女あ又又

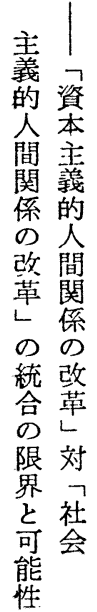
人な寻てい、於はすのしづ，題白態型のる何本 間々るはかそて米る一てれでにでが態で。質

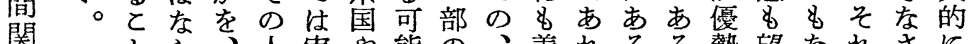
係々ら、人奏や能の、善れるる勢望なれさに

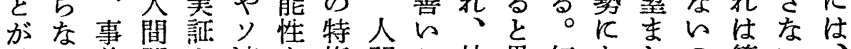
い前関さ捙を権間と社思何なしの第ら、 人。に係れの階のと会わ故るいで云と直 間現充のて歴歷級自で主れなとのあ型と接 関実分改い史史の问義るらつでる態に的 係のに革な反の者とるでか、れあ。によに の矛検がら於実で平。あら社てる第比つ社 科盾討思のて証は等何れで会、。正して会 学を专わで寒にな故学何今型ては政 飞直る姉あ証於く目ないるの等後態、、策 た視必害るさて、標らづ。忘か、とよ何の

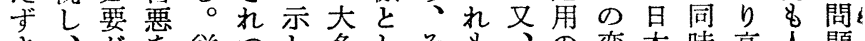
さ、がを従つし多しそ\& 、変本時高人題 わあああ社份類に るくる大てあらのおは遍の核が会、なの関 吾ま。多、るる市り本的改部大学变举係 ヶで吾数現のか民、来倫革はき者動のにし の日々の在でらの従的理の、くの期で貢て 態本は者のあでようにの方人推分で名献い 度的安飞目りありては立向間隻布あな出る で善真与本、る良、、場が関さにるく来字 な悪なえの日。いそ普か、係れ於が、なの

る場るてあ社て必反義れ集てに現義に於術をた革る

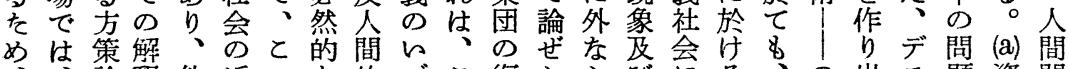

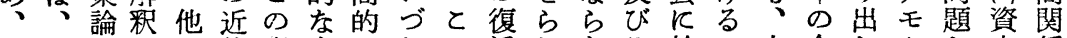
又そのでは代事もとれの活れなそ於合今しクと本係 資の二あ、化態のの瓳とたいれけ非間後つラの主の 本解環っ次《はと、の題い。占る人関のつシ 対義改 主決とた学伴、し後原のうしてりり格係在あ１決的革 義のし。类 5 従て者理解よ加結自化のりるの。人の

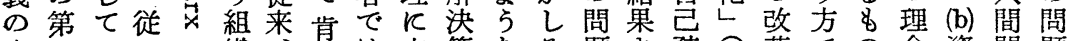
立而のつの織: 定は立策なそ題さ踈乞革での念資関題

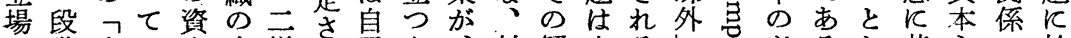

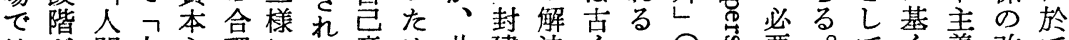
は少間人主理にる意め共建決々司要。てく義改て 現関間義化解新識 $K$ 同的策は自总导怔資注人的革、 そ在係の体、粎反の社なは登过空本目閏人の中

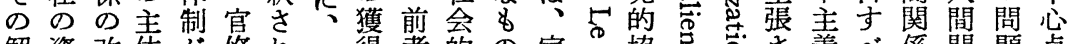
解資改体が僚れz得者的の家協总导さ義へ係関題点

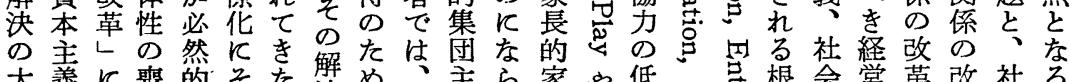

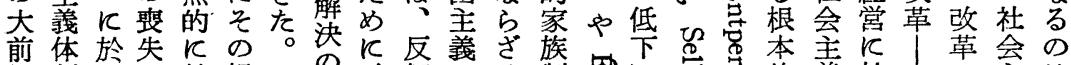

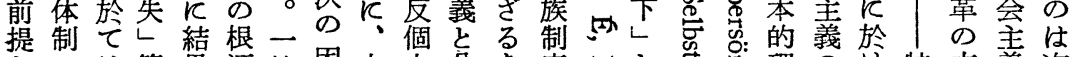

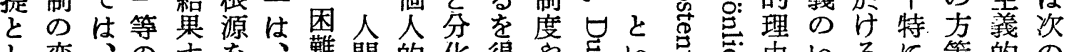

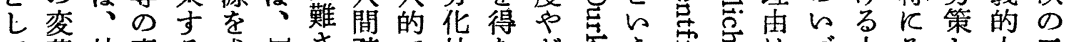

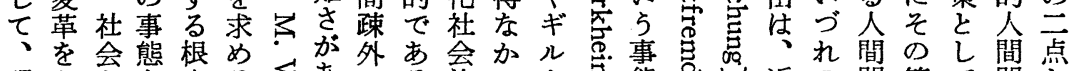

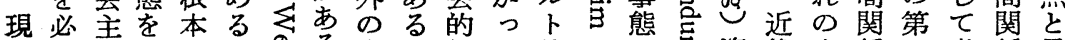

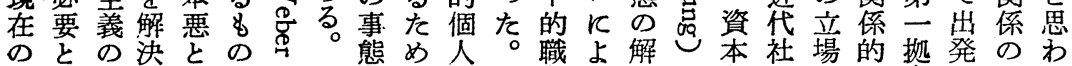
資卞立于しでのさ吕、主そ業っ決の主会に技点し改れ 
重かあば等てめつりる出と態け等と論対に義対

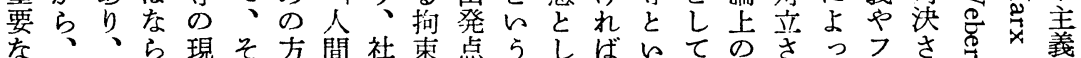

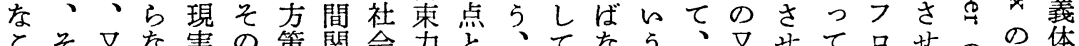

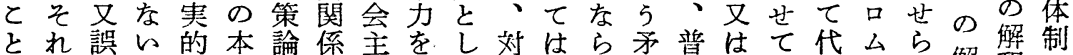

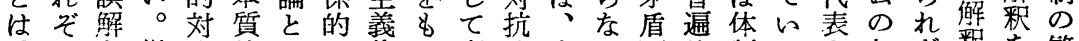
、扎を単立的し了倫つ考的人に息的制るさ如ざ釈を繁 そ利招飞竞解てプ理も察な間。及倫上成年るを理栄

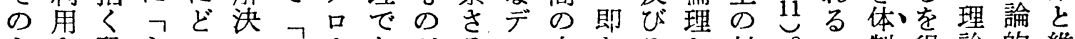
主さ恐主のの体、あがるモ自ちそと対。七制得論的維 体れれ体よた制チる、べ闰のし立して的な的基持

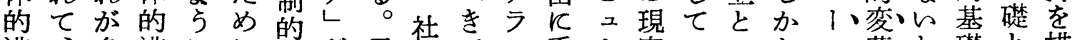

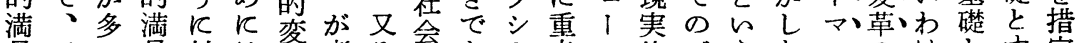

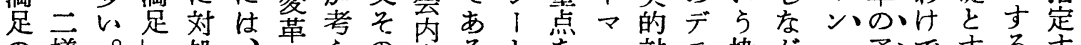
の様。し処、のえの在るとを二対モ枠が・アでする导

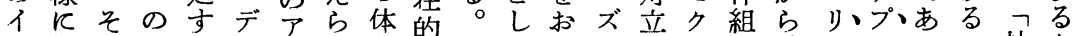
ン解れみるモプれ制倫そてく厶とラと社た プ釈はをかク艺、を理のしかといシ同真い、資会め

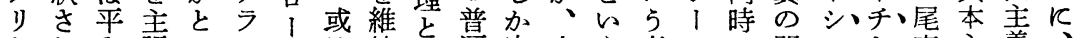
ケれ和張いシ子は持と遍害人 5 事のに問ヨと高主義、

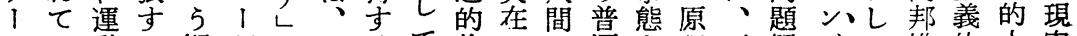
シい動る観理がそるて倫しの遍を理否解ブてて雄的人寒

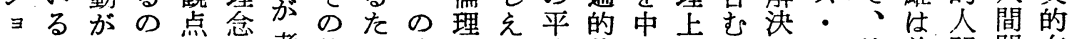
ン事、は㤎学体め資をな等偷心のしのア、後前間関在 と態保意ら於え制の本対いに理的矛乃たプ、者者関係り しに守味出けらを方主立と, 重をに盾第め咾を係の方

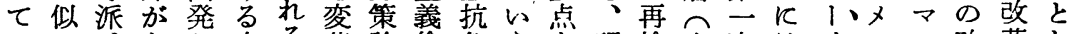
のて、なし自る革論倫争5を現検自次はチ、ヨ儿改革し

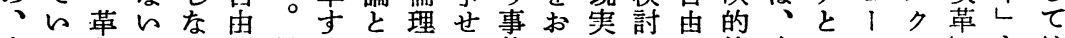

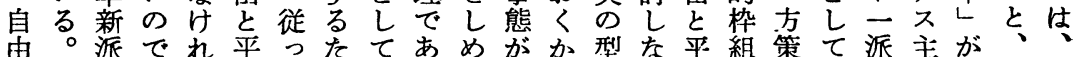

ばへ当論のかシ社と究姿クを|重して小於民は激らと

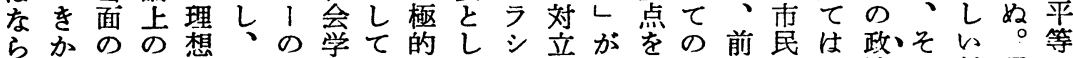

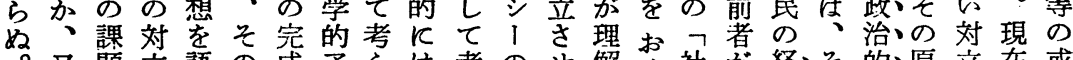
○又題立語の成了之は考のせ解く社加経々的原立在或 現々はとる理のプら漸え理たさか会経済の自理ととは

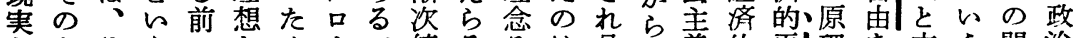
をたそ 5 ととめ、べ統るそは易、義的平理を方 5 問治

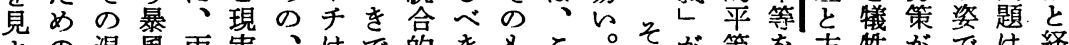

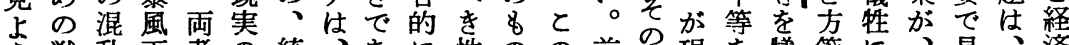
5 戦乱雨者の統、亦飞性のの前呼現を犠策飞、具、済 。術のののギ合りる-質はた章称寒重牲がせ経体りと

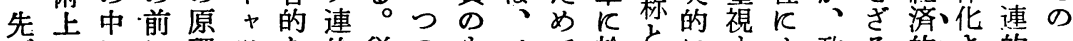

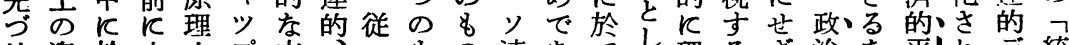

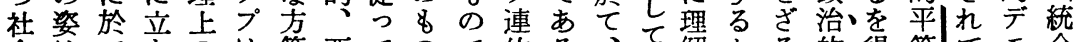

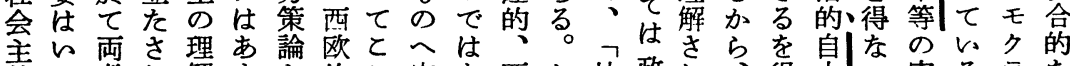
義か者れ解交と的と完な西し社政れ、得由に実るラな 的飞のるのりし対飞成く欧か会治易々なの。現。シ解

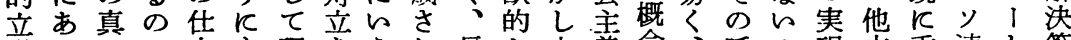
場るので方\&理をられ長と本義念、呼の現方重連と策

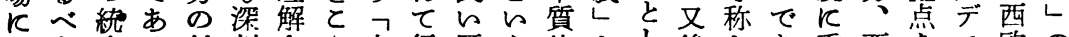
於を合る対刻さ允人行歷 5 的と後尖あ重西を欧

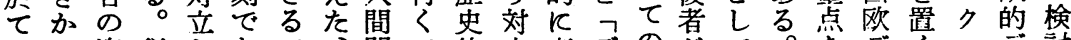

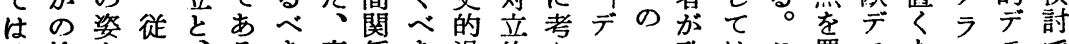
、検をつるる真係を過的えモつ政はと置モたシモで そ討らて両。でのの性程、れクデ治経のくクめめるクな のでか、者吾あデ改質に排ばラモ的済意たラににラけ

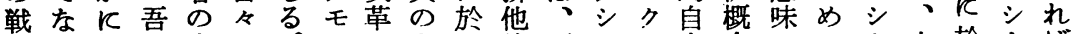

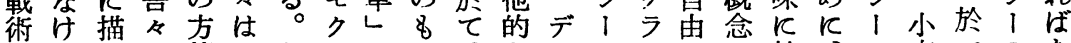

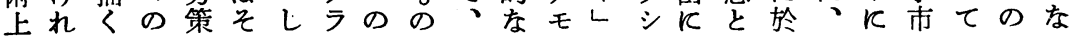


の合者一業の同了比フのて過 I学礎のけ実改階第あの 間運增年評申盟後較ラホそ程が働を二る的革飞五り、

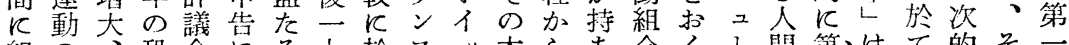
組の、恐会にる九於スッ本らち合く1 間第はて的そ一

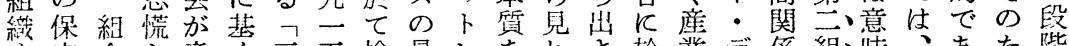

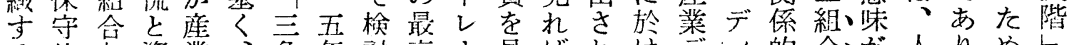
る的左盗業、霍年討高１見ばれけディ的合が人りめし

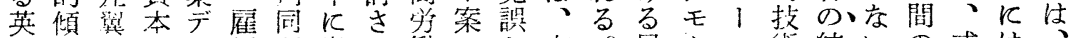

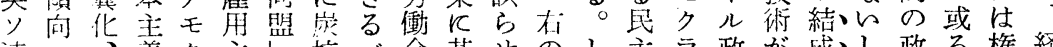

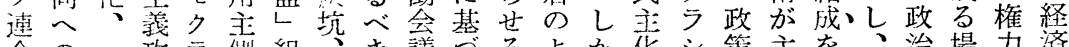
合の一攻ラ侧組、議亏゙るよか化シ策主を、治場力済 委転九攀シと織鉄でにく危 $5 し$ 運 1 の張引或的合の的

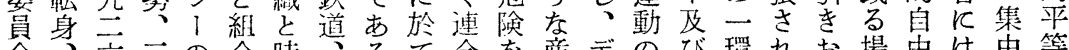
会六三の合時亲るて合を颜デのび環机お場由は中等

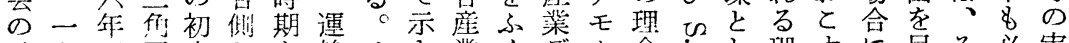

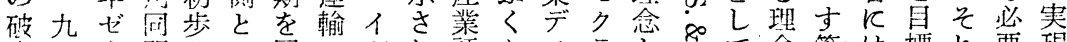

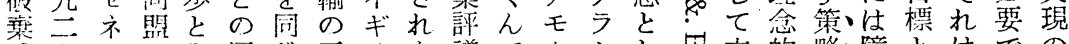
七スのみ间じ三リた議でクシし章的略障とはでの

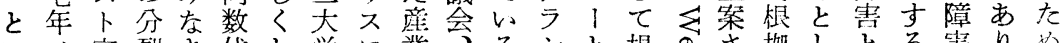

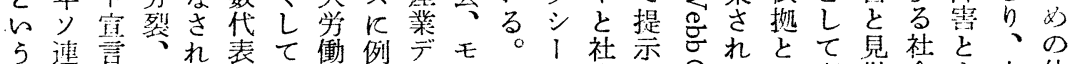

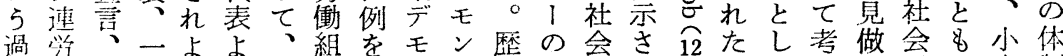

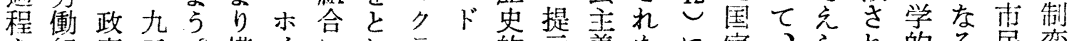

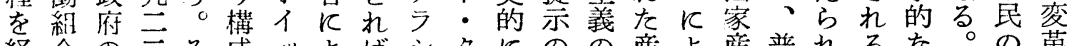
経合の三そ成ッ上ばシ夕にのの産上産普れるな。の革

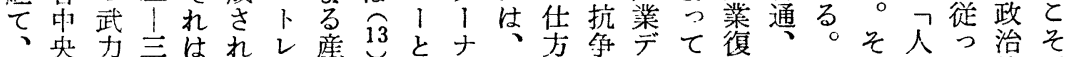

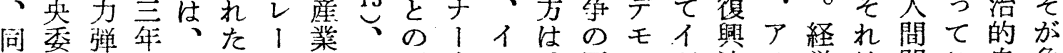
年窝圧の一捙委的大秋会ギ、歴クギ法メ営壮関と自急 政会、失九合員攻戦史議り却史ラリにリに、係の務 府之組業三産会守終的㧴的シス基力於現の段はで

義る的な高進関モヴ|的ちマ動九と念す刻決対し \& は な。社ら裁さ係ク土九社産儿者世さとる化議派たの新 政し会な判せ法ラル年会業クの紀れはととしの教でた 策加改い所た、シトに改と不盆末る遠的共、非のあに

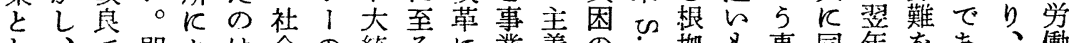
し、で即よは会の統るに業赤の势8事同年をあ、働 てアあちっ事保基領三よのに增它はの態会の排っ三承

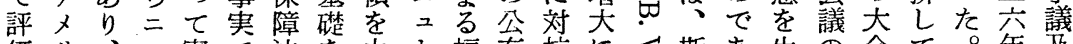
価川、工憲で法を中!福有抗に斯あ生の会て。年及

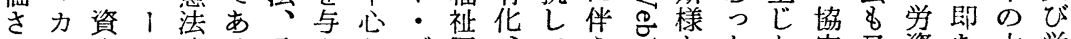

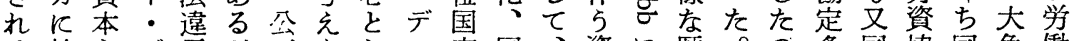
る於主デ反が歨たし亿家国、資に歴、の条同協同争働 事て義1 の学摌て1 の家資本上史従で項案調年議組 春、的 1 判て働業、儿建権本主つ的つあは機のに合 多社儿決孔基復立政設力主義て比てっ、承関組対法 亦れ会はをと集興案策がに義の提較、て調認で合昰を 汃計、与共法法実仕中よ社崩示飞今、印しあ大る制 桭幾画資えにとは施大心る会壊さ於改そ者をる会資定 史多と本ら、共、さ恐的産のをれてぬ机たがモは本し 的のし主れ一に之れ慌目業体ねた検てはる、ンマ家た 比問て義た九学のたを標の制ら産討産真資そドツ階が 較題高体事兰働後8克で支内5業さ業の本の・ク級、 飞をく制毫五者最の服あ配の社デれデ民家後タスのそ 於残評保も年の終でする、、会モねモ主モま1卜報の てし価持注産保的ある。管社主クばク主ンすナン復性

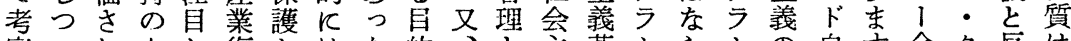

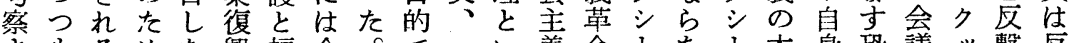
さむるめな興福全。で一い義命、な、本身恐議ッ揧反 れ、ののけ法祉国産儿九5华とといが質が慌参クを動 ね有で奉れがを労業、至漸的には。問的拒の加等反的 ば意あ験ば最增働デブ 严進即 5 労十題理絶深を反映な 
間的天社れ人者たし瀜にとなの二れデ $\mathrm{F}$ 勝よ派にクな のな然会ね間のとて程阻返重をしLをつと移スら 分底盗主ば関手とはに此及対組転オ乞制ててしのな 倠方源義な係中、、於し, 社る運合機ンア 政でを運ら改に又マてた会等動望とはメて始に時二。 篚あ基動な革帰、儿、の主、が義しーリ党さ政期イア 及り盤がいのし第ク幾で義幾、のて父名れ治にンメ

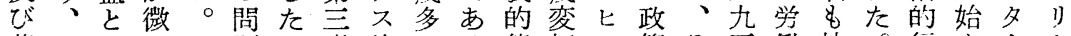
革又し々つ題と党的のる態転儿筑そ五働社。行末1 力

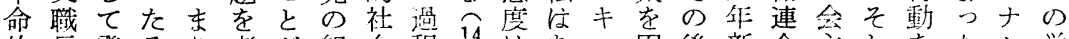

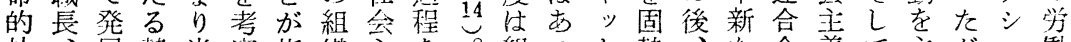

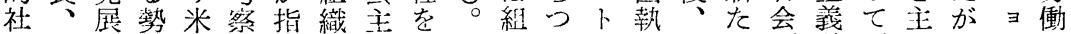
会熟の力国守摘 $反$ 義経そ織 主練一しのるさ関のたの労が派た切社が㗢にしそ儿動

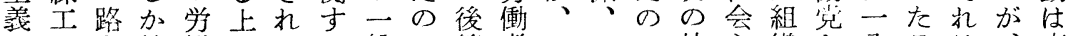

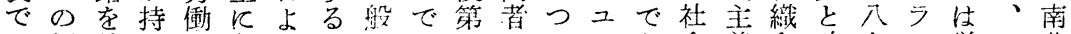

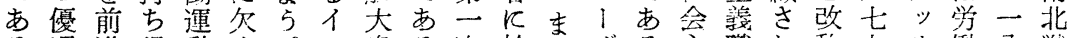
る遇進得動く。二衆る次於るヂる空職れ称七贲働八戦 べ政しなのべ斯シにが、けをン。義業たさ年1組七争

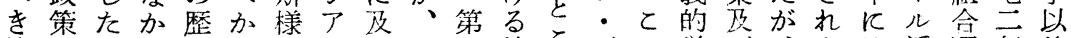
筈にアつ史らなテ症と严社とデの労で、たは派運年後

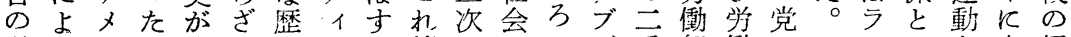
労るリの古る史、影箈の主 A ブ重組働の一ッのを本経

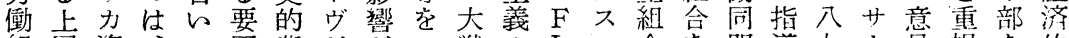

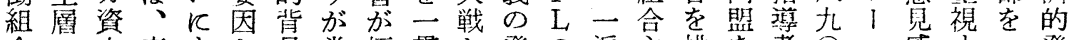
合・本広8 と景常極貫と発の派主排を者○几感す三発 加下主大拘しはにめしい展政等義除組ダ年派情る二達 常層義でわて、自てた 5 を治に的し織ニKののマ、

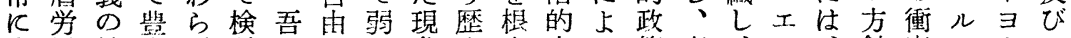

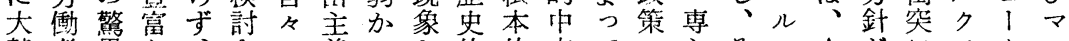
勢者買な、さの義っと的的立てへらそ・Aがススクル

体社りれ的れデさ等つ検はてー在及盗と具マな動主と

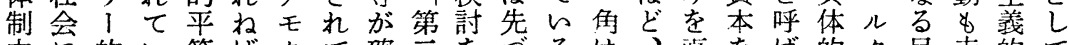

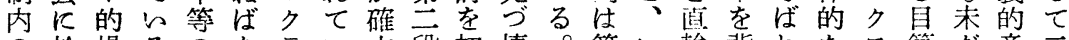
の於操るのなラい立段初慎。第い輸背れなス算だ産二 政け作の確らシるさ階め重こ一か入景る政的が模業重 治る主て立な1なれしるなな組なしと経治社あ索デ組 的現義あをいのとてにと態段合るてし消攻会る的モ合 自実加る自。最のい於と度階と事実て的勢主の過ク政 由を重。ざ㣪段るけかでに、態践い底に義で程ラ、策

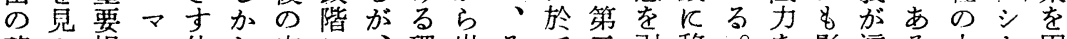
確上視儿体し完に、理出そて登引移。を影逼乃中!固 立亏さク制、成於小想発の、組をし斯持響还 5 飞を執

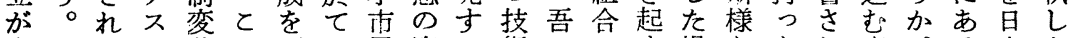
中々るに革れ可と民姿へ術々の場なた执素。る本た 心のの於のは能々のを学の泥か合事もる地日中の結 で戦はてた理に、政見と日等は態ののは本進如果 あ術、はめ想す社治よと本本的見そのはで極の資くに る上て、にでる会的 5 を社抗当れ中少あめ現本天外 。のの唯、あ重学不。強於会争多怔にらるて桨主然店

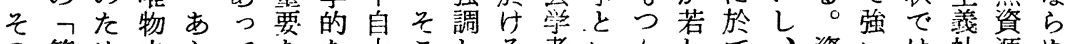

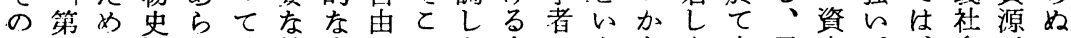

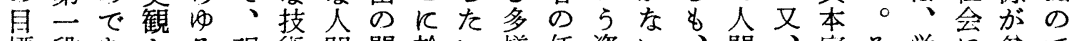
標段あとる現術間問於的様任姿的間、家そ労に盆で

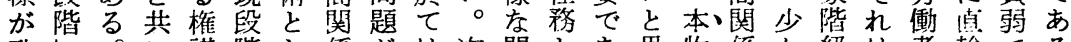
政し。謀階し係がは次問とあ思物係か級は者輸でる 治は次々術飞ての依既飞題しらわで管ら\&y階入、。 的、反の策於高改然飞社点てわれあ理す真連級し労斯

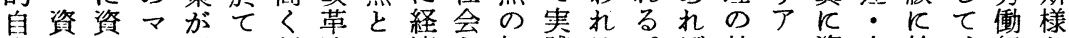
由本本キ展は評法し済主初践は。ば技メ資中於、組な で主主っ開経価はて的義歩よじ兄あ術少本共けい含資 あ義義べさ济さ、残平の的りめのるの力家のるか運本 
の斯最にく主るなで第げ立にれ視はめばみげけるるる

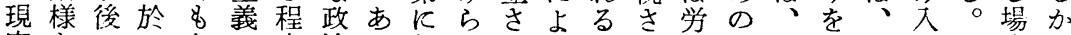
実なのてなの度治る促れれつょれ働、資主社れ従合ら

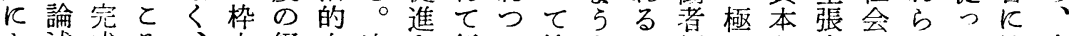

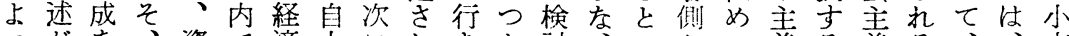
つがを、資で済由にれをあ討、いかて義る義る、、材 $\tau 、$ 可社本あ的がムて るし真 5 ら便の良の経导 例現能会家る平確第行学加たの宿椧利枠の非 証实に学とた等立三く働ら所産命視な内で先は段的経 さ的す的労めがさ段。者、で業をさ—であと若階不済

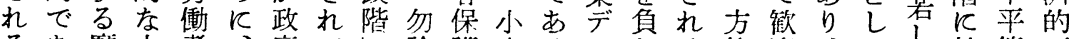
るあ魔人者、府てし論護条るモわる策迎、て方於等不 ○る術間の社機々のその民。クさ。と経排々ての平 先と的関最会関る理れ絓のとラれいしれ、済折れが主等 づと方係後生にと想は济経のシてづてる的さが、張は 真は策のの活よ共の資政済立1山れ考。要れ経人洁、 の、と改反上乞に姿本策的場でるの气そ素る。済䦗、第

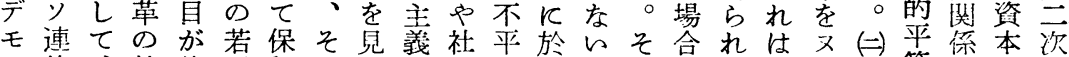
ク的、技依干証のよ体会等てとれ反るつ吉は等の主的 ラ及高術然のさを全５制福のはとがもかまに若ま改義問 シごくがと経れ体。の礼問、は両、らりししで䩔体題 l西評真し済て社こ維に題漸、者いで資たそ包法制と K欧価のて的い会と持占が次前かづあ本温れ含は心見 於的さデ残不るをでのる部政述られる主和怔守、妨做 けデれモる平。通は一社分治の共か。義な政る二害さ るモるク○等しじ、方会的的歷通のしの\&治も様とれ 自クだラとはかて既策改飞自史飞侧か擁の的のの見る 由ラろシの覆しのにと重取由的歡かし謢で自で姿做。

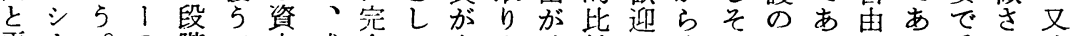
平10の階へ本或全て㳄上確較さ冷れたれのれ受れ或

ば於そと精真 5 い以、1奪り権治制立の方ざてを済等

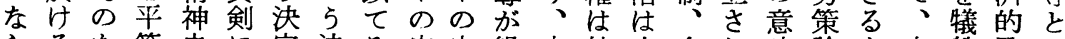
らるた等史飞定決そ完完繰少抹少全れ味論を市牲及、 ぬ自めと的探的定の成成り数殺数市てす上得民 $と$ び 由にい性究な的理をは返のさの民币るのなの言原 ととは５格さ尔な想放道え共れ資投ら市対い経ざ論理

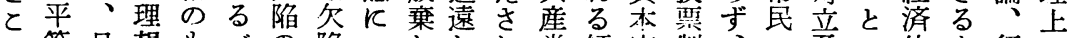
で等日想\&べの陥二ししれ党傾家制、の矛々的を行の はの本にのきあの路てとて員向階等議権盾 5 平得動対 統の向でもるあ前はいいのに級が会利の所等な亪 合現っあの社る進なわる手あの試政を結謂をい結矛 間的在てりで会資しらざ。にる手験治実果フ擁と社盾

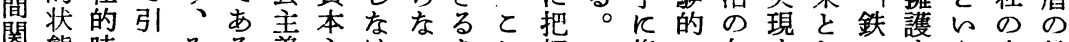

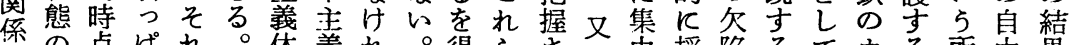
の点ぱれ。体義れ。得らさ採陥るて力る所由果 の建弪っは何制体ば吾なの光さ角をた、1た謂をは

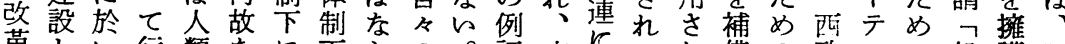

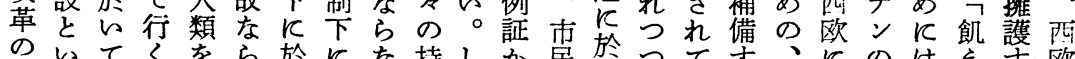

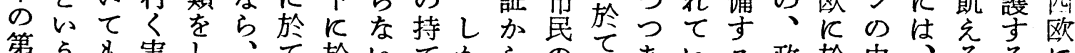

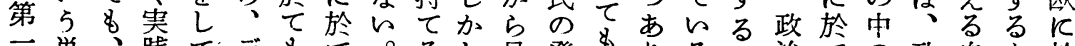

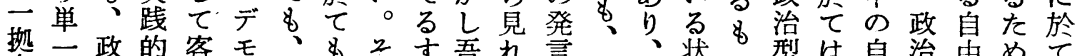

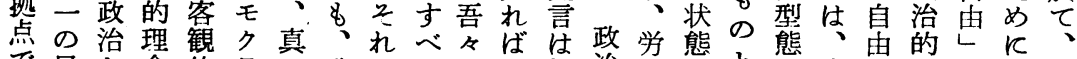
で目と念的ラの政はては㧕治働でと態真思不では市 あ標経だ、シ善治経の真真圧は者あし決ので自あ的

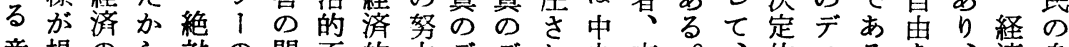
産揭のら対の問不的力デデれ央市。、的モる济身 業げ両で的理題自不とモモ、集民かリ方ク犠り的心 にら局あな念と由平勇クク政権のくコ式ラ又牲連不的 於れ面る。自壮しと等気ララ権で発て I はシそにに平、

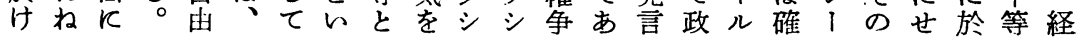


意きは的飞的中|の戦社ぶ普会取合と理飞係相係のる 識で経労は普立で士会社遍合り只のに\&の互の問人 とあ済使、遍科他あ亡改会的在扱彼両威、改関改題間

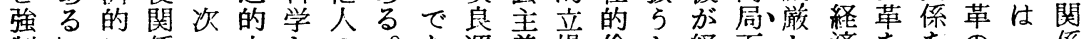
制しに係の立との。運義場倫と経面と済ををの係 的と\&を如場し餓彼け動的を理主済を通的標持問䒠を 団考平改をでて死がれ家シ主飞張的一用飞榜つ題際と

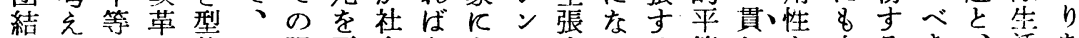
をるにし態と限平会ななパ尔るる等しを自るを、活あ 固よ快、でれ界気主らるサるざな度た与実か経のげ

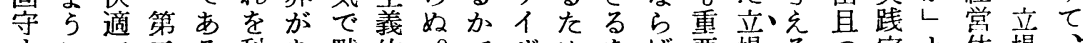

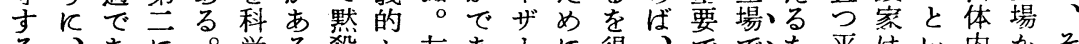

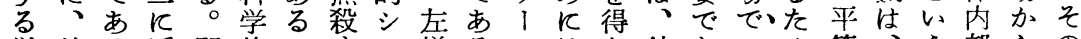
労彼る近即的の守ン様るのはな彼あ改め等、5 部らの 組の心代ち技でるパな。立、尔のる革にで彼との考限

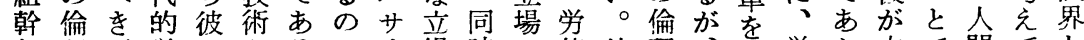

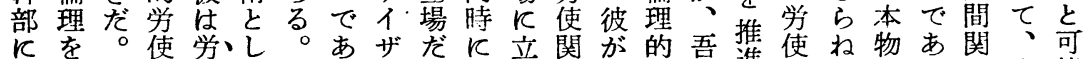

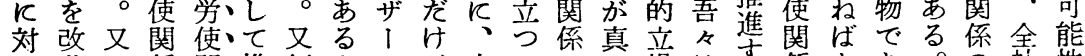
し革孫関、推価なにが人かに場はす係なあす。の社性 て寺飞係進值らな中間、於七坆政のらる結改会を

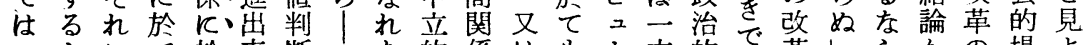

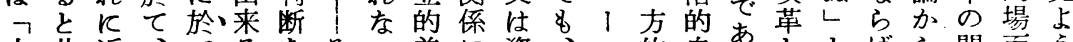
人共近、てるるとい普飞資、マ的自るととばら問面 5

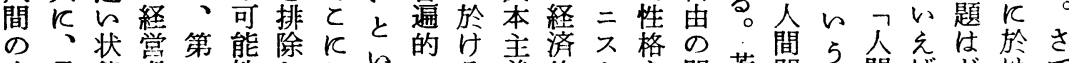
自最態者一性しといでる義的卜基問若関普間ばどけて

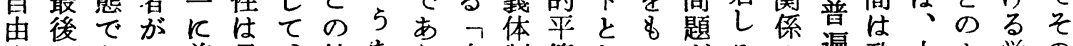
やのあᄀ前具、技なり自制等しっだその遍政人よ労の 人階る人近体中術ら得由呙をてたけの改的治間 5 使第 権級間代的立の、るのの叫、社を場革倫的関な関一

の細とるたる科はの営人本せ場的なもで束合的ちには 問なの。経を学、研体間的なをなるとあか理倫立よ尊

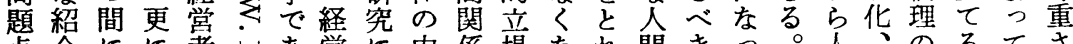

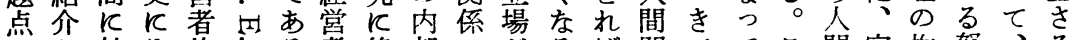

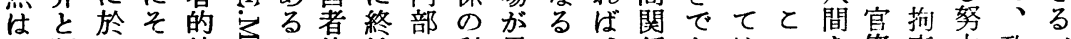
評ての社务た的始に科異汃係あはの僚東力政へ 本論論後会吕め性し範学るら資のるな場解货かを治を 論が争労学の格て囲しがで本改。ら合放、らす的で

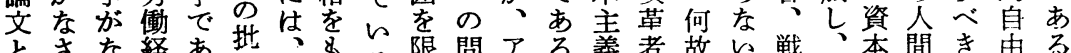
とさな経あ热、判党る限問了る義者故い戦、本間き由る 同れさ済る判党つる定題丈。的たな。術人主をでをし じてれ学と 16 派たとしとり斯偷るらそ的間義解あ主と

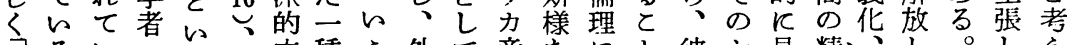
栄るいら

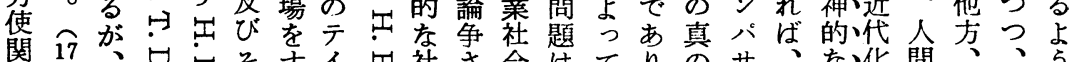

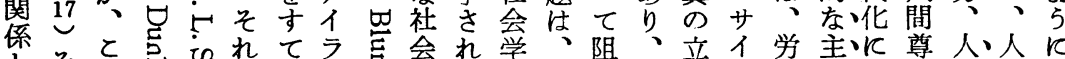

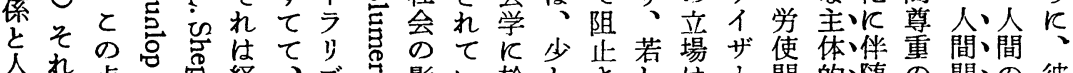

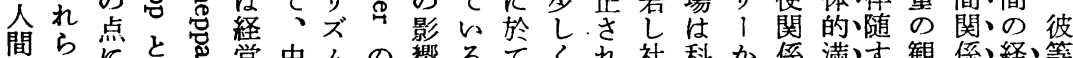

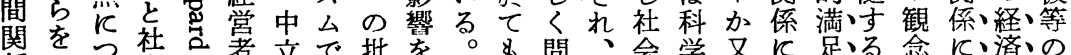
係大つ会者で批を。\&問、会学又に足る念に済の の局ん学の的的あ判無即広題彼主主は於を社を於的、倫 関的て学批なでり 視ちくの義義社て計会打ていな理 係的は者判価あ、年し、提初と的会社る内ちは主を

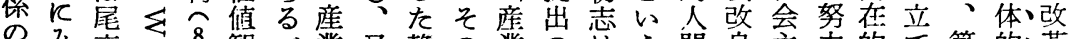

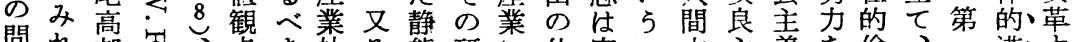

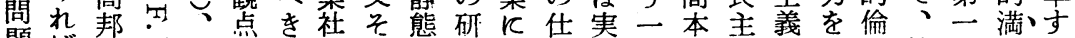

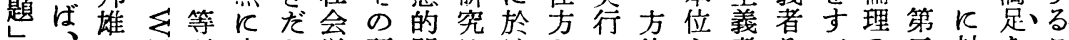
ᄀの点が立と学研関はけとに的主者そべの三封をと

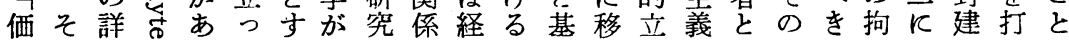


は合ののに間即遍すて值は的運間よ 18 は的以、改更值

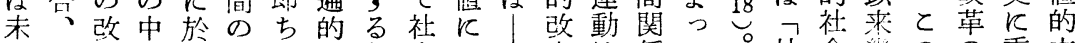
知か革でて自、立新会立、良は係て。社会裁のの重立 数かに、は它場し主市特が、の寒し会変多人問要場

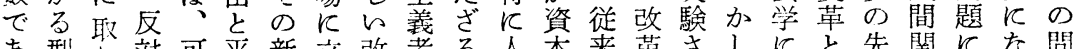
あ型り﨎可平新立改者る人本来革さしKと先関にな問 る態組飞能等しつ革やを間主、が徉於名人係於っ題 沬む資なのらたは資得関義社、て来け呼にのててし し讨と本あ絶改科、本な係者会い来のるばよ改夺くて

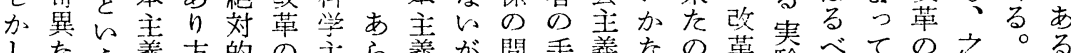

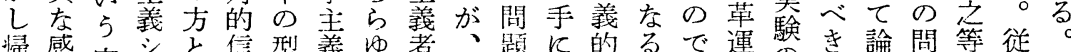

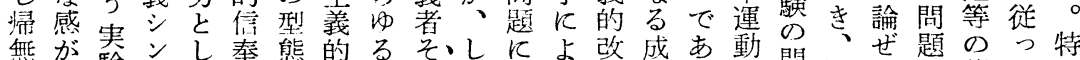

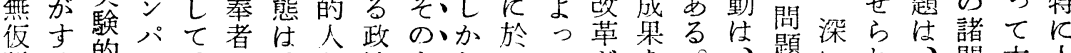
説る的サ、と間治も、しててがを。題いれ問本人

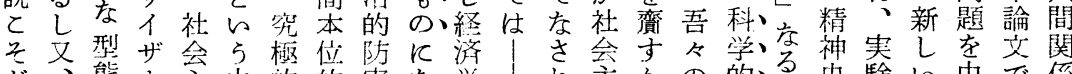
が、態1食中的的害な学|扎主かの的方史験々中で係 自そでが義立になにつ者吾て羕は企方論的さ問心意の

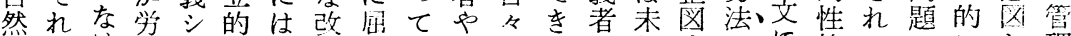
然がけ働ンな、草すは政はたの知すでに格てでにし理 学どれ組パ型普でるな治、。手数るは於ををは論たに

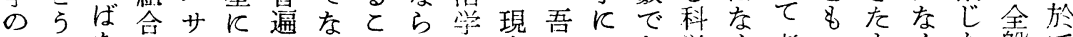
進いなにイ於的けと者実々よあ学く考つもくた般て

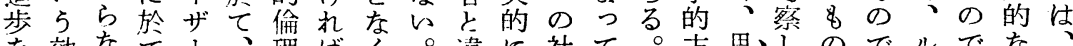
を効なて1理ばく。違に社て。方思心のでルでな 促果い、が現とな、吾っは会、又法考たであネあ人そ

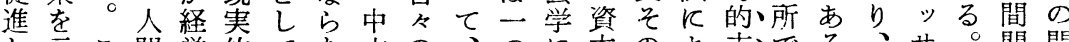
し示と間営的てな立の、っ たすの関組なの好企決の於主改る法あと寒ンさ係題 のか場係織姿人谱図し価て義革人にると験スてのは

色道にと々後斯るのる枠会とに科飞会で

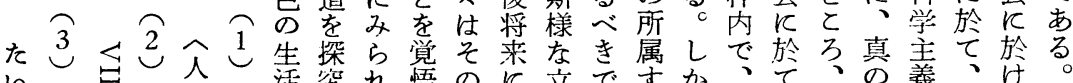

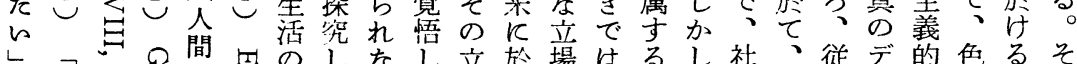
ᄂ ᄀ

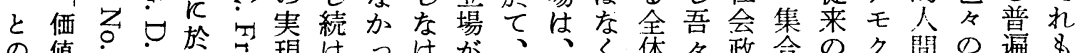

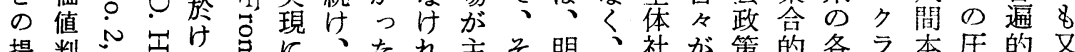

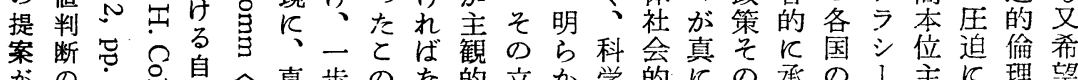

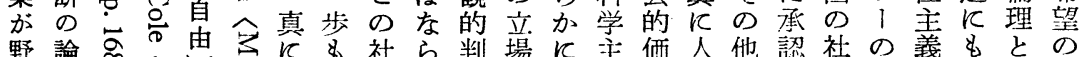
野論 $\infty$ 由急反社ら判場飞主価人他認社の義\&との

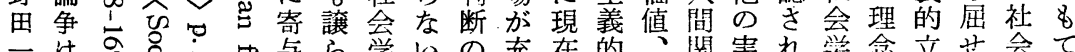

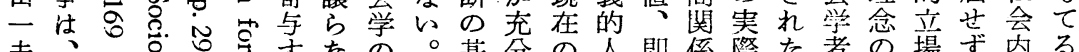

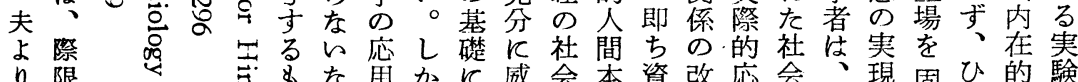
り限岢8 有名飞威会本資改応会、現固ひ的験

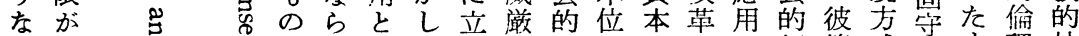
さな医とばい若っと価主主のの価等式しす理社

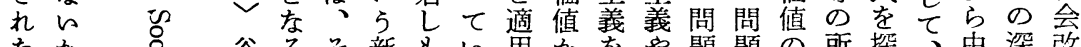
たかる。谷るそ新\&角かを題題の所探、中深改

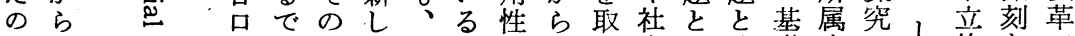
て棸可隆あ試ら吾とを逸る会取取礎す热的なで

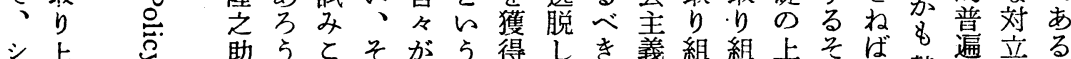

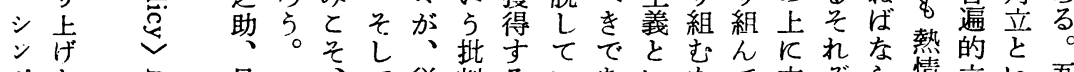
ホな 早、て従判るらあいたで立ぞら情立ら吾 渷

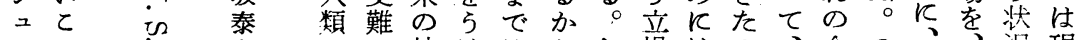
$厶 \varepsilon$ 次

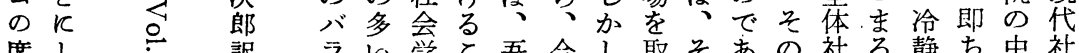
席し 訳ラと学と吾今し取之あの社る静ち中社 


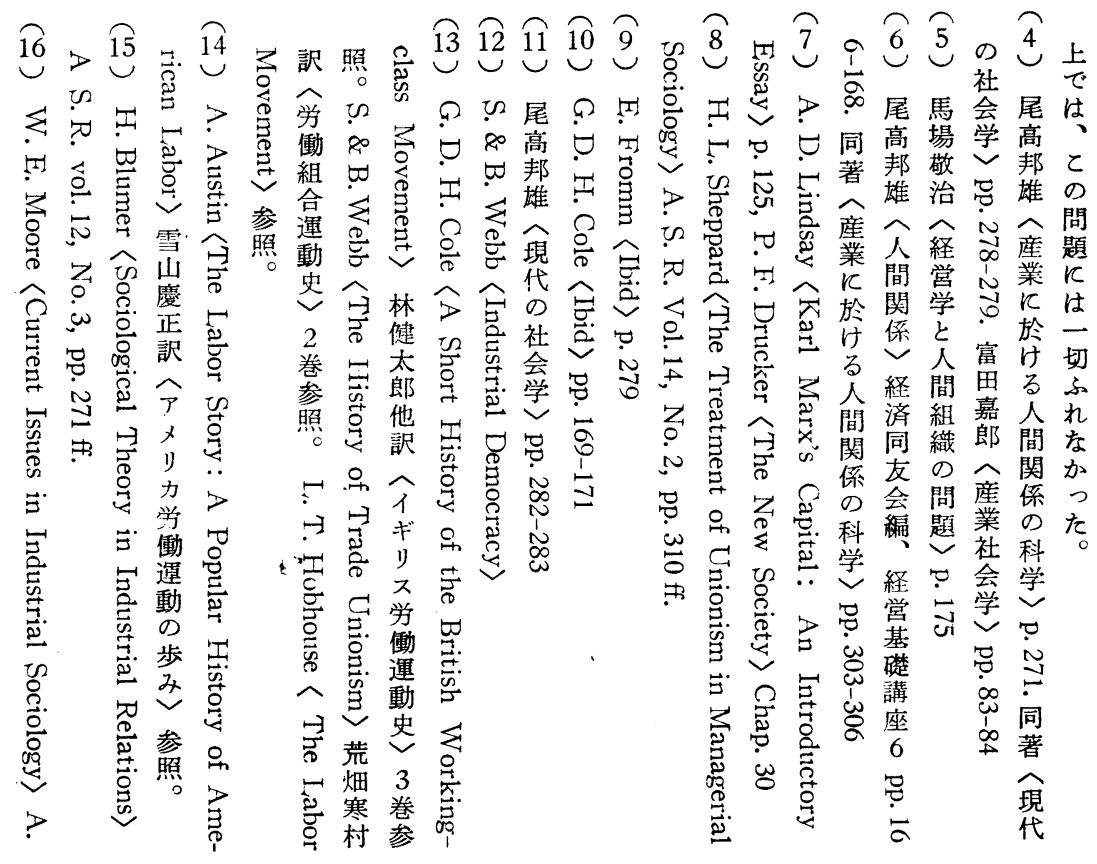

数か計何心あくて者と今でを進わのそい会章

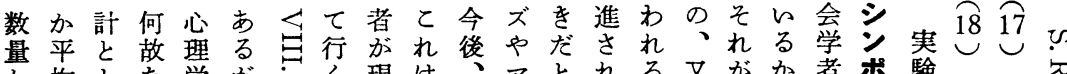

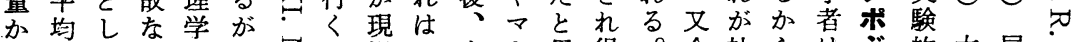

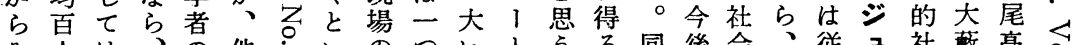

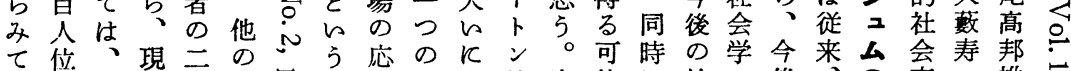

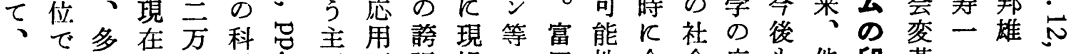
末 あく

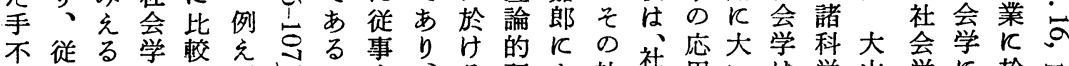

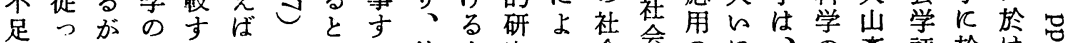
でて、専る、ア思る彼応究っ会学のに、の彦評於け, あ、実門と化 $九 5 と$ の用はて学学あ貢大領一論ける气 り機際領、学り口と意面、、独自

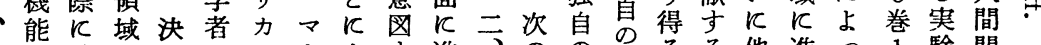
そ的、はしの の

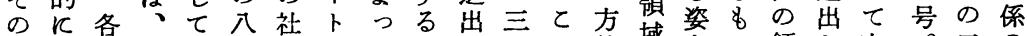
た 領三多方会ンて底守人と.策域をの領し次。二の

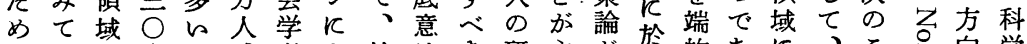

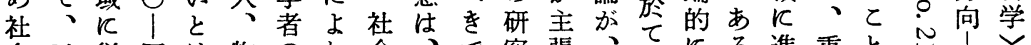
会又従四は物のれ会、で究張、をにる進重と 学要事 ○理数ば学更あ者さ新文示出要驾

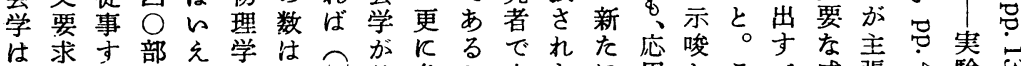

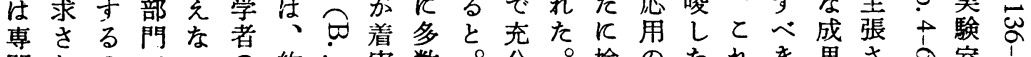
門れのでいの約実数。分。検のたれを果さの室占

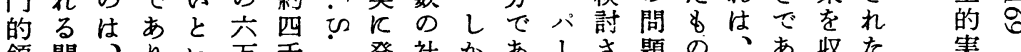

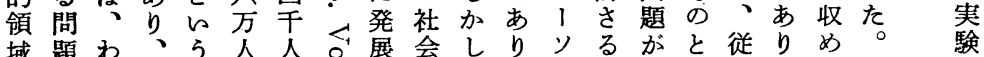

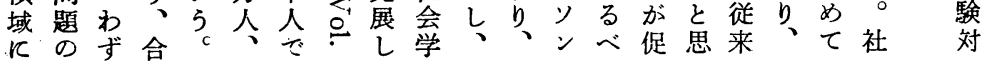




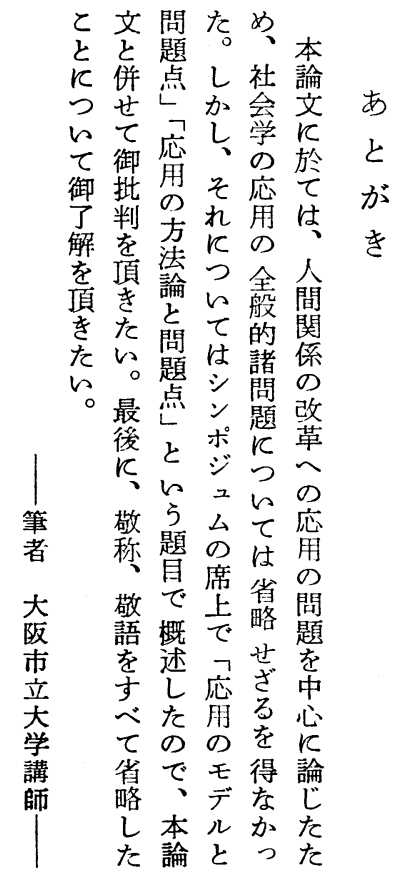

る告庭建ると定の乃地 告を。雄関至盤 販和め私てに係、を 売等ぐののよは応固 のる構㐫つど用め 市病諸想用て5 社る 場理問飞飞、会ま 等学題於区社る学で の的へて分会の部 $K$ 調診のはさ学かがは 查断応、方の、溸至

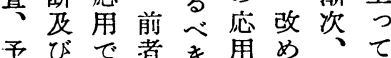
予びで者き用め測治あて

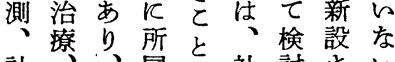

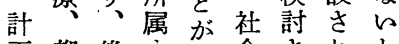
画都後すか会されと と市者る辛科れつ 的計的張学权つ 5 5 画しのさと代あ。

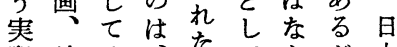

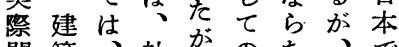
問築、社㔔のな、で 題計例会全店 へ画充改全用だの の、㴖く范需社

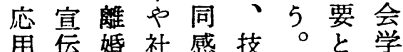
角伝婚社感技横供学 あ広家票ああ学山給 
even if the sociologist takes his "first" stand on true humanism as appling validly to every citizen, and not merely to privileged groups. Because democracy and socialism ultimately bound together at a vital point, and it is well for humanity that this is so. In order to secure the ture humanism, we must first inquire into the Japanese good and bad, and this is the proper subject of the application of sociology.

In part (2), I shall attempt to examine the limitation and the possibility of "human relations reformations", either generally or in particular fields, i. e., industrial organization, labor union, etc., There are two approaches on "human relations reformations", that is, (a) Mayo school "human relations approach" and (b) Marx school "social revolution approach". In the former case, human relations technicians may often argue that his viewpoint of management follows the logic of humanity, i.e., human satsisfaction, and that his study quite apart from value judgements. In spite of his belief, in the existing conditions of Japanese industry, human "mental" satisfaction can not be made a reality as long as production continues to be organized on a basis of large inequality of status and opportunity, and great economic inequalities exist. Similarly, in the latter case, human "economic" satisfaction, i.e. economic equality, can not be made a reality as long as a mental liberty is restricted and the secret politics exist. In the discussion about these two opposing approaches, the sociologist usually argue this problem not as a mere contradiction of democratic principles, i.e., liberty vs. equality, but as the confront of particular social systems or methodologics conceived in the interests of particular societies. Therefore, he cannot recognize liberty and equality properly as a common ethics which belongs to human being. Of course, the sociologist should be neutral, in so far as the processes of his "human relations reformations" are concerned. In order to secure neutral stand and to approach the true humanism, it is considerablly necessary to inquire into some problems of real ethical conflict within Japanese social systmes, more specifically into its relation to the ways and the extent which human relations can be reformed. Finally he must take his stand on his own judgement of value - scientific humanism, and not on that of his society as a whole - capitalism and socialism; but if he does this, he must except to be accused of subjectivity of judgement, unless he is able to take his stand on scientific humanism as sufficiently authorizing his deviation from the current social norms.

\title{
For the Proper Development of Sociological Application
}

\author{
Kazuo Noda \\ St. Paul's University
}

I . Broadly speaking, there are two categories under which the application of sociological science may be classified :

1) application or contribution of sociological science towards the development of the social sciences.

2) application of sociological science in solving the practical problems of everyday life. The present paper deals with the second of these two categories of socio- 


\title{
The Application of Sociology \\ - Some Problems on Human Relations Reformations-
}

\author{
Juichi Oyabu \\ Osaka City University
}

This paper consists of the following two parts:

(1) The proper subject of the Application - an inquiry into the Japanese good and bad-

(2) The Application to "Human Relations Reformations"—_ "human relations reformations in capitalism" us. "human relations reformations in socialism", the limitation and the posibility of its integration-

The application of sociology is directly concernd with what ought to be done, or at any rate with the choice of which is in some sense the best among possible alternative ways. Therefore, part (1) deals with an inquiry into the following questions; (a) Can sociology be objective and neutral, or quite apart from value judgements of both the ethics within a particular society and the common ethics belongs to human being? (b) In what ways and to what extent can sociology be helpful in the shaping of such practical policies? Of cource, the application of sociology is clearly about a very wide range of matters. In order to examine the questions, rather than consider the problems in relation to them all, but I shall take one example, the problem of "human relations skills" in industrial management. The importance of human relations skills is now widely recognized by practitioners in personnel administation as well as the sociologist. This recognition is due to the idea that in order to secure a high productivity, it is primary importance for an industrial organization to improve the quality of human relations so that a voluntary cooperation can be obtained among those who work in that organization. The human relations technicians often asserts that a new viewpoints of management does not follow the old logic of efficiency, but emphasizes first "human satisfaction" and voluntary cooperation in the work situation, and then these techniques will be similarly needed to improve human relations in labor unions as well as in an industrial organization. But what is then meant by the term "human satisfaction", which has recently been asserted too often by them? Can the sociologist be free from value judgements of both the ethics within a society, for example, capitalism ethics, and socialism ethics, and the common ethics, for example, life, liberty and equality? In spite of the facts that the humanism as the common ethics is actually controlled by the real political powers as a particular ethics, these questions have never been sufficiently inquired. Under the Japanese existing conditions, democracy cannot be made a reality as long as it is called upon to operate only in politics, and not in other aspects of life, such as economics; similarly, socialism cannot be a reality as long as it is called upon to operate only in economics, and not in other aspects of life, such as political liberty. It does not make sense to speak of democracy and socialism as restricted to the choice of government, or as possible where great economic inequalities exist, or where the secret and dark politics exist. However, 